\title{
BOUNTIES FOR BAD BEHAVIOR: REWARDING CULPABLE WHISTLEBLOWERS UNDER THE DODD-FrANK ACT AND INTERNAL REVENUE CODE
}

\author{
Jennifer M. Pacella*
}

In 2012, Bradley Birkenfeld received a \$104 million bounty reward from the Internal Revenue Service ("IRS") for blowing the whistle on his employer, UBS, which facilitated a major offshore tax fraud scheme. Birkenfeld does not fit the mold of the public's common perception of a whistleblower. He was himself complicit in this crime and even served time in prison for his involvement. Despite his conviction, Birkenfeld was still eligible for a sizable whistleblower bounty under the IRS Whistleblower Program, which only excludes from reward eligibility those convicted of "planning and initiating" the underlying action. In contrast, the whistleblower program of the Securities and Exchange Commission ("SEC") under the Dodd-Frank Wall Street Reform and Consumer Protection Act ("Dodd-Frank") precludes rewards for any whistleblower convicted of a criminal violation that is "related to" a securities enforcement proceeding. Therefore, because of his conviction, Birkenfeld would not have been granted a bounty under Dodd-Frank had he blown the whistle on a violation of the federal securities laws rather than a tax violation. This Article will explore an area that has been void of much scholarly attention - the rationale behind providing bounties to whistleblowers with unclean hands and the differences between federal whistleblower programs in this regard. After analyzing the history of these federal programs and the public policy concerns associated with rewarding culpable whistleblowers, this Article will critique the IRS's practice of including the criminally convicted among those eligible for bounty awards

* Assistant Professor of Law, City University of New York, Baruch College, Zicklin School of Business. I am grateful to Miriam Baer, Kathleen Clark, Karie Davis-Nozemack, Dennis J. Ventry, Jr., and David Zaring for their helpful comments on earlier drafts of this Article. I would also like to thank the participants of the Annual Conference of the Mid-Atlantic Academy of Legal Studies in Business and the City University of New York, Baruch College, Department of Law Faculty Scholarship Series for their feedback during presentations of this Article. 
by giving focus to alternative whistleblower incentive structures, such as leniency and immunity. This Article will suggest that the SEC's approach represents a reasonable middle ground that reconciles the conflict between allowing wrongdoers to benefit from their own misconduct and incentivizing culpable insiders to come forward, as such persons often possess the most crucial information in bringing violations of the law to light.

INTRODUCTION 346

I. SEC AND IRS WHISTLEBLOWER PROGRAMS .........................................351

A. Structure of the IRS Whistleblower Program ..........................351

B. Dodd-Frank Introduces a Bounty Model.................................355

II. REWARDING CULPABLE WHISTLEBLOWERS........................................359

A. Bradley Birkenfeld's Bounty..................................................359

B. Should the Law Allow Culpable Whistleblowers to Be Rewarded?

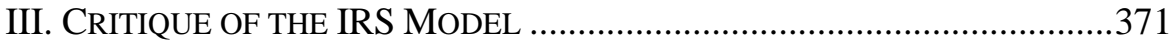

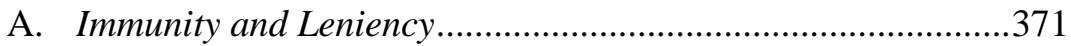

B. The "Planned and Initiated" Determination............................381

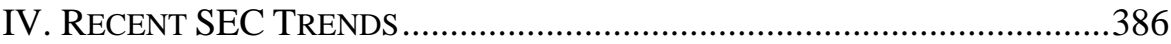

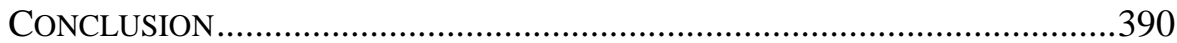

\section{INTRODUCTION}

The public's perception of whistleblowers has evolved drastically in recent years. Traditionally perceived as "snitches," "rats," or even "crazy," whistleblowers have increasingly emerged as heroes possessing the courage to address corporate wrongdoing. ${ }^{1}$ The emerging importance of

1. See, e.g., Elletta Sangrey Callahan, Terry Morehead Dworkin, Timothy L. Fort \& Cindy A. Schipani, Integrating Trends in Whistleblowing and Corporate Governance: Promoting Organizational Effectiveness, Societal Responsibility, and Employee Empowerment, 40 AM. Bus. L.J. 177, 189-90 (2002) (discussing public policy's maturation in favor of whistleblowing); Geneva Campbell, Snitch or Savior? How the Modern Cultural Acceptance of Pharmaceutical Company Employee External Whistleblowing is Reflected in Dodd-Frank and the Affordable Care Act, 15 U. PA. J. Bus. L. 565, 571-75 (2013) (discussing the recent distrust of corporations as one reason for an increased sense of acceptance of whistleblowers); Yuval Feldman \& Orly Lobel, The Incentives Matrix: The Comparative Effectiveness of Rewards, Liabilities, Duties, and Protections for Reporting Illegality, 88 TEX. L. REV. 1151, 1159 (2010) (stating that "[i]n the past, popular culture has generally portrayed whistle-blowers as 'lowlife[s] who betray[] a sacred trust largely for personal gain.' In recent years, however, the act of whistle-blowing has been reshaped in the media as a heroic act that can bring deeply corrupt practices to a halt."); Jonathan Macey, Getting the Word Out about Fraud: A Theoretical Analysis of Whistleblowing and 
whistleblowers as a source of essential information in fraud detection has changed the way in which they are viewed by society. In 2002, Time magazine named three whistleblowers as persons of the year-Sherron Watkins of Enron, Coleen Rowley of the FBI, and Cynthia Cooper of WorldCom-each of whom disclosed information pertaining to major corporate wrongdoing within their organizations. ${ }^{2}$ More recently, in 2013, Time chose National Security Agency whistleblower Edward Snowden as runner-up for person of the year, naming him "the doomsayer of the information age." 3

Whistleblowing has been described "as an institution" and as one of the most notable developments in corporate governance and law enforcement in recent decades. ${ }^{4}$ Today, tips from whistleblowers account for over 40 percent of all reported occurrences of occupational fraud. ${ }^{5}$ The role of whistleblowers in fraud detection is crucial, as insiders have the most accurate access to information about misconduct and wrongdoers' attempts to hide their behavior. ${ }^{6}$ It has been argued that many of the financial scandals of the twenty-first century could have been avoided if established and effective whistleblowing programs had been prevalent,

Insider Trading, 105 МicH. L. REV. 1899, 1901 (2007) (noting that whistleblowing has recently become "fashionable," garnering a rise in popularity after historically being viewed with suspicion); Robert A. Prentice \& Dain C. Donelson, Insider Trading as a Signaling Device, 47 AM. Bus. L.J. 1, 63 (2010) (acknowledging the distinct popularity of recent whistleblowers who possess "that patina of near-sainthood"); Matt A. Vega, Beyond Incentives: Making Corporate Whistleblowing Moral in the New Era of Dodd-Frank Act "Bounty Hunting," 45 ConN. L. REV. 483, 491 (2012) (noting that the public perception of whistleblowers has transformed from "morally suspect" to heroic).

2. Richard Lacayo \& Amanda Ripley, Persons of the Year: Cynthia Cooper, Coleen Rowley and Sherron Watkins, TIME, Dec. 30, 2002, http://content.time.com/time/magazine/ article/0,9171,1003998,00.html.

3. Michael Scherer, Edward Snowden, The Dark Prophet, TimE, Dec. 11, 2013, http://poy.time.com/2013/12/11/runner-up-edward-snowden-the-dark-prophet/.

4. Vega, supra note 1, at 485; see Richard Moberly, Sarbanes-Oxley's Whistleblower Provisions: Ten Years Later, 64 S.C. L. REV. 1, 4 (2012) (stating that Sarbanes-Oxley was a successful model for whistleblower law).

5. See Frederick D. Lipman, Whistleblowers: Incentives, Disincentives, AND Protection Strategies 2 (John Wiley \& Sons, Inc. 2012) (discussing contemporary changes in whistleblower regulations).

6. See, e.g., Justin Tyler Hughes, Equity Compensation and Informant Bounties: How Tying the Latter to the Former May Finally Alleviate the Securities Fraud Predicament in America, 82 S. CAL. L. REV. 1043, 1062 (2009) (claiming that many corporate scandals of 2002 were exposed due to inside tips); Geoffrey Christopher Rapp, Mutiny by the Bounties? The Attempt to Reform Wall Street by the New Whistleblower Provisions of the Dodd-Frank Act, 2012 BYU L. REV. 73, 83-85 (2012) (stating that OSHA employees may lack the necessary training to act as gatekeepers under Sarbanes-Oxley). 
which would have allowed information to flow directly to the boards of directors without the risk of management misleading directors. ${ }^{7}$

Whistleblowers have uncovered some of the most significant injustices pertaining to social, financial, environmental, and economic issues, attaining heroic status in the minds of many and highlighting a moral element to whistleblowing. Given the enormous risks that potential whistleblowers face in their careers and the perception of disloyalty to colleagues that reporting is likely to convey, the decision to blow the whistle is often an ethical one. ${ }^{8}$ There are many emotional and social hurdles to reporting information about one's colleagues and friends, and whistleblowers have commonly described their experience as a "'nightmare,' and a venture 'fraught with dangers and risks.",9 Whistleblowers often face retaliation for their efforts, such as exclusion from work activities, verbal abuse, lack of promotions or raises, and relocation or reassignment. ${ }^{10}$ Often, whistleblowers are ignored or labeled as crazy, vengeful, or unworthy of being taken seriously, despite the fact that the information they have to offer may indeed be true. ${ }^{11}$

Given the admirable status that whistleblowers have recently attained in society, what should we make of whistleblowers who are themselves complicit in the wrongdoing that they are reporting? This question becomes even more complex when considering that whistleblowers with

7. LIPMAN, supra note 5, at 2.

8. See Lili Levi, Dangerous Liaisons: Seduction and Betrayal in Confidential PressSource Relations, 43 RUTGERS L. REV. 609, 710 n.363 (1991) (noting that scholars have described the decision to blow the whistle as an ethical duty that involves moral issues given the conflict with the notion of organizational loyalty).

9. Geoffrey Christopher Rapp, Beyond Protection: Invigorating Incentives for Sarbanes-Oxley Corporate and Securities Fraud Whistleblowers, 87 B.U. L. REV. 91, 118 (2007) (citing Pamela H. Bucy, Private Justice, 76 S. CAL. L. Rev. 1, 61 (2002) and Leonard M. Baynes, Just Pucker and Blow?: An Analysis of Corporate Whistleblowers, the Duty of Care, the Duty of Loyalty, and the Sarbanes-Oxley Act, 76 ST. JoHN’s L. REV. 875, 882 (2002)).

10. LIPMAN, supra note 5, at 63-65.

11. See, e.g., Barbara Ettore, Whistleblowers: Who's the Real Bad Guy? 83 MGMT. REV. 18 (1994) (claiming that more than half of whistleblower reports are ignored); Rapp, supra note 6, at 118 (asserting that although negative views of whistleblowers may be prevalent, that does not mean that the whistleblower "has not spotted genuine and serious fraud”); John-Paul Ford Rojas, Banker Labelled 'Crazy Miss Cokehead' after Whistleblowing, Tribunal Hears, TELEGRAPH, Feb. 28, 2013, http://www.telegraph.co.uk/ finance/newsbysector/banksandfinance/9898708/Banker-labelled-Crazy-Miss-Cokeheadafter-whistleblowing-tribunal-hears.html (describing how a whistleblower was harassed at work); Jack Welch \& Suzy Welch, Whistleblowers: Why You Should Heed Their Warnings, FORTUNE, May 29, 2012, http://fortune.com/2012/05/29/whistleblowers-why-you-shouldheed-their-warnings ("In the vast majority of cases whistleblowers are, to some degree, crazy or vengeful or both. Until one terrible, awful day when, speaking out of vengefulness or ethical earnestness, the whistleblower also happens to be telling the truth.”). 
unclean hands are not precluded from receiving bounties or cash rewards for providing information to either the Securities and Exchange Commission ("SEC") or the Internal Revenue Service ("IRS”) about securities law and tax law violations. There are differences, however, between the two programs' treatment of culpable whistleblowers. Under the Dodd-Frank Wall Street Reform and Consumer Protection Act ("DoddFrank"), the SEC may pay bounty awards to whistleblowers who voluntarily provide original information that leads to an SEC enforcement action in an amount between 10 and 30 percent of the total monetary sanctions collected in that action. ${ }^{12}$ The SEC denies bounties to certain types of whistleblowers, including "any whistleblower who is convicted of a criminal violation related to the judicial or administrative action for which the whistleblower otherwise could receive an award ....”13

Although securities whistleblowers who are also convicted criminals are excluded outright from receiving a bounty, the SEC still makes bounties available for those who are complicit in the wrongdoing, although the SEC may decrease an award depending on the whistleblower's involvement. ${ }^{14}$ In deciding whether to give a bounty on the lower end of the scale, the SEC will consider factors such as the whistleblower's role in the securities violation, whether the whistleblower acted with scienter, the egregiousness of the fraud committed by the whistleblower, and the timeliness of the report. ${ }^{15}$

In contrast to the SEC's complete preclusion of bounties for convicted criminals, the IRS takes a broader approach to its tax whistleblower program, which was amended in 2006 under the Tax Relief and Healthcare Act to enhance the long-standing ability of the IRS to reward informants. While the IRS has a long history of rewarding individuals who provide it with information pertaining to others' violations of the Internal Revenue

12. 15 U.S.C. § 78u-6(b)(1) (2012 \& Supp. I 2013). The language of Dodd-Frank pertaining to bounties reads as follows:

In any covered judicial or administrative action, or related action, the Commission ... shall pay an award or awards to 1 or more whistleblowers who voluntarily provided original information to the Commission that led to the successful enforcement of the covered judicial or administrative action, or related action, in an aggregate amount equal to (A) not less than 10 percent, in total, of what has been collected of the monetary sanctions imposed in the action or related actions; and (B) not more than 30 percent, in total, of what has been collected of the monetary sanctions imposed in the action or related actions.

Id.

13. Id. § 78u-6(c)(2)(B) (emphasis added).

14. 17 C.F.R. $\S 240.21 F-6(b)(1)$ (2014). The culpability of the whistleblower is just one of the criteria that the SEC will consider in determining the bounty amount.

15. Id. 
Code ("IRC”), ${ }^{16}$ the 2006 amendments to the IRS whistleblower program introduced mandatory bounties, rather than discretionary, thereby increasing the availability and size of rewards for tax whistleblowers. ${ }^{17}$ These amendments also recognized that tax whistleblowers may themselves be culpable, but nevertheless allowed for bounties to be paid to whistleblowers who are convicted of tax law violations, with one caveat: the whistleblower's conviction must not be based on a role in which such person "planned and initiated" the underlying action. ${ }^{18}$ Therefore, the IRS's preclusion of bounties for criminals is only applicable if the tax whistleblower played a leadership role in the wrongdoing and was convicted because of that specific role.

This Article will analyze the differences between the SEC and IRS whistleblower programs, specifically with respect to the issue of granting bounties to culpable and convicted whistleblowers-an area lacking in scholarly attention. Section I will begin this comparison by examining the IRS whistleblower program, including its long-established bounty program and the 2006 amendments that made the program what it is today. This Section will also explore the newly-enacted SEC whistleblower program, its defining characteristics, including its basis on the IRS bounty structure, ${ }^{19}$ and how the program differs from that model.

Section II will provide an in-depth examination of whistleblower Bradley Birkenfeld's story-from his conviction for his role in UBS's offshore tax fraud scheme to his receipt of a \$104 million bounty from the IRS for blowing the whistle on UBS. This Section will also explore why whistleblowers with unclean hands should never be disregarded as sources of key information pertaining to violations of the law.

Section III will offer criticism of the IRS whistleblower program's inclusion of those who are criminally convicted as eligible for bounty. This Section will suggest that the existence of alternative whistleblower incentive structures, such as leniency and immunity, are more appropriate for a potential whistleblower facing a criminal conviction, especially in light of Bradley Birkenfeld's motivation to come forward with his

16. See Karie Davis-Nozemack \& Sarah Webber, Paying the IRS Whistleblower: A Critical Analysis of Collected Proceeds, 32 VA. TAX. REV. 77, 82-83 (2012) (describing the history of the IRS whistleblower program).

17. Tax Relief and Health Care Act of $2006 \S$ 406(a)(1)(D), Pub. L. No. 109-432, 120 Stat. 2922 (codified at 26 U.S.C. § 7623(b)); see Davis-Nozemack \& Webber, supra note 16, at 82-87 (describing the IRC enhancement that recognizes that a whistleblower may be culpable when blowing the whistle).

18. 26 U.S.C. $\S ~ 7623(b)(3)$ (2006 \& Supp. V 2012); see also Davis-Nozemack \& Webber, supra note 16, at 86 (describing the IRC amendments as they pertain to complicit whistleblowers).

19. S. REP. No. 111-176, at 111 (2010). 
knowledge of the UBS tax fraud. This Section will also explore the ways in which the IRS whistleblower program strays from the structure upon which it was based: the qui tam program of the False Claims Act, which rewards private citizens, even if complicit, for offering information regarding individuals who are defrauding the federal government, but excludes the criminally convicted from any award. ${ }^{20}$ This Section will suggest that the SEC's approach represents a reasonable middle ground that reconciles the conflict between allowing wrongdoers to benefit from their own misconduct and incentivizing culpable insiders to come forward.

Section IV will then draw parallels between the enforcement missions of the SEC and the IRS to refute arguments that the two agencies are so divergent as to justify their differing treatment of convicted whistleblowers. This Section will examine recent trends suggesting that the SEC has strongly emerged as a "punisher", utilizing enforcement structures that are more akin to a criminal enforcement agency like the IRS. In this way, the enforcement mechanisms of the two agencies may be more alike than presumed. It is the author's hope that this Article will invite further scholarly discussion on this topic, as legislative history of the applicable statutes and legal debate are lacking in this controversial area of whistleblower law.

\section{SEC AND IRS WHISTLEBLOWER PROGRAMS}

\section{A. Structure of the IRS Whistleblower Program}

The IRS has rewarded informants since the nineteenth century. Codified in present-day Section 7623 of the IRC, the IRS began rewarding persons providing information about tax noncompliance in 1867 under legislation that gave it "the authority 'to pay... sums as ... deem[ed] necessary for detecting and bringing to trial and punishment persons guilty of violating the internal revenue laws or conniving at the same.",21 Until 1996, the IRS made these payments from a pool of appropriated funds, but subsequent legislation was enacted that changed the source of rewards to the proceeds of amounts collected from the taxpayer. ${ }^{22}$ The 1996

20. 31 U.S.C. § 3730(b) (2012 \& Supp. I 2013).

21. IRS WHISTLEBLOWER OFFICE, FISCAL YEAR 2010 REPORT TO THE CONGRESS ON THE USE OF SECTION 7623 (2010), http://www.irs.gov/pub/whistleblower/annual_report_to_ congress_fy_2010.pdf [hereinafter 2010 REPORT]; Davis-Nozemack \& Webber, supra note 16, at 82; see also Brian H. Mahany, The IRS Whistleblower Program: What CPAs Should Know, Tipsters, IRS Profit from 2006 Reforms, J. AcCOUnTANCY 50, 51 (2009) (noting that few changes were made to the IRS informant/whistleblower program between 1867 and 1996).

22. 2010 REPORT, supra note 21 , at 2 . 
amendments also included the detection of tax underpayments among the types of information that would qualify whistleblowers for a bounty. ${ }^{23}$ During this time, awards for tax whistleblowers were only discretionary, allowing the IRS to grant awards to whistleblowers of one, ten, or fifteen percent of the proceeds with a cap at $\$ 10$ million, which the IRS sometimes waived. ${ }^{24}$

The IRS whistleblower program continued in this manner until June 2006, when the Treasury Inspector General for Tax Administration ("TIGTA") conducted an audit of the program upon the request of Congress. ${ }^{25}$ Although the TIGTA audit uncovered the broad success of the program, it also revealed weaknesses in the discretionary structure of the reward model, including under-utilization, administrative problems, and a lack of clarity as to the defined incentives of whistleblowers. ${ }^{26}$ The TIGTA report prompted new legislation to strengthen and enhance the IRS whistleblower program. ${ }^{27}$ Through amendments passed in 2006 as part of the Tax Relief and Healthcare Act, a new and improved IRS whistleblower program was born. The ability of the IRS to grant discretionary awards was retained, though on a non-percentage basis, which is codified in present-day Section 7623(a) of the IRC. ${ }^{28}$

The 2006 amendments also created the new Section 7623(b) of the IRC, which established a centralized IRS location, the Whistleblower Office, to receive and administer whistleblower tips and determine bounty

23. Id.; Davis-Nozemack \& Webber supra note 16, at 82. Earlier versions of tax whistleblower rewards did not provide much of an incentive to report and were also underutilized by the IRS.

24. 2010 REPORT, supra note 21 , at 2.

25. See Davis-Nozemack \& Webber, supra note 16, at 84-85.

26. Id. (citing TREASURY InSPECTOR GEN. FOR TAX ADMIN., THE INFORMANTS’ REWARD Program Needs More Centralized Management Oversight (2006), http://www.treasury.gov/tigta/auditreports/2006reports/200630092fr.pdf). In its audit report, TIGTA expressed that, in 32 percent of cases, it was unable to determine the justification for the reward percentage awarded to informants and, in 76 percent of rejected claims, it was unable to determine the reason the reviewer rejected these claims. Id.

27. Id. at 85 ("Senator Charles Grassley, the champion of the Whistleblower Program and author of the 2006 reforms, persuaded Congress to significantly overhaul the Whistleblower Program following the TIGTA report.").

28. 26 U.S.C. $\S 7623(a)$. Present-day Section 7623(a) of the IRC states:

The Secretary [of the Treasury] . . . is authorized to pay such sums as he deems necessary for (1) detecting underpayments of tax, or (2) detecting and bringing to trial and punishment persons guilty of violating the internal revenue laws or conniving at the same, in cases where such expenses are not otherwise provided for by law. Any amount payable under the preceding sentence shall be paid from the proceeds of amounts collected by reason of the information provided, and any amount so collected shall be available for such payments.

Id. 
awards. Section 7623(b) implements a mandatory, rather than discretionary, bounty structure for tax whistleblowers of at least 15 percent but not more than 30 percent of the collected proceeds, including penalties, interest, and additional amounts that result from any administrative or judicial action that the IRS has taken based on the whistleblower's information. ${ }^{29}$ To qualify for a bounty, the whistleblower's information must relate to a business tax noncompliance matter "in which the tax, penalties, interest, additions to tax, and additional amounts in dispute exceed \$2,000,000,” and, when the information relates to an individual taxpayer's noncompliance, a bounty is only available if that individual's gross income exceeds $\$ 200,000$ for at least one of the applicable tax years. $^{30}$

The Whistleblower Office determines the appropriate amount of the award. It grants a minimum of 15 percent or a maximum of 30 percent of the collected proceeds from the IRS action, based on "the extent to which the individual substantially contributed to such action." 31 The bounty award can be decreased to 10 percent of the collected proceeds if the Whistleblower Office determines that the whistleblower's information is principally based on allegations disclosed in certain sources of public information, such as a governmental report, hearing, audit, investigation or news media coverage. ${ }^{32}$ A whistleblower can also appeal his or her award determination to the United States Tax Court. ${ }^{33}$

The IRS whistleblower program makes bounties available to culpable whistleblowers complicit in the tax violations, with variations in reward amounts based on the individual's level of involvement in the tax noncompliance. As stated in the IRC:

If the Whistleblower Office determines that the claim for an award... is brought by an individual who planned and initiated the actions that led to the underpayment of tax or actions ... then the Whistleblower Office may appropriately reduce such award.

29. Id.

30. 2010 REPORT, supra note 21, at 3; see also Davis-Nozemack \& Webber, supra note 16 , at 85 (noting that Congress intended to use this program as a way to obtain maximum returns in relation to the cost of the program by targeting "high dollar tax abuses."). One other scholar notes that the high threshold for tax whistleblower awards is likely to defer most claims to the discretionary program of Section 7623(a). Edward A. Morse, Whistleblowers and Tax Enforcement: Using Inside Information to Close the "Tax Gap," 24 Akron TAX J. 1, 18 (2009).

31. Id. § 7623(b).

32. Id. § 7623(b)(2)(A); see also 2010 REPORT, supra note 21, at 3.

33. See id. $\S 7623(\mathrm{~b})(4)$ (stipulating that appeals must be filed within 30 days of the award determination). 
If such individual is convicted of criminal conduct arising from the role described in the preceding sentence, the Whistleblower Office shall deny any award. ${ }^{34}$

Therefore, the IRS Whistleblower Office may decrease the amount of a bounty for culpable whistleblowers that planned and initiated the tax noncompliance action and may outright deny a bounty to tax whistleblowers convicted because of that particular leadership role. In other words, the IRS still provides a bounty to a convicted criminal who participated in the tax violation but did not plan and initiate the wrongdoing. As the IRS seems to have acknowledged, "promoters of tax shelters and tax fraud are not surrounded by boy scouts and angels," 35 and often have unclean hands. After all, "[y]ou need someone whose hands are dirty to find dirt." 36 Information from those complicit in the violation unquestionably involves details that would otherwise be difficult to locate. The IRS Whistleblower Office receives information from individuals who discover tax noncompliance in any number of ways, including through the individual's workplace or daily personal business. ${ }^{37}$ "Anecdotal evidence suggests that the [IRS] often receives tips after a relationship has gone bad, be it a familial, romantic, or business relationship. It is this type of intimate relationship that often provides for the 'detailed inside knowledge that will be the most beneficial in bringing forward tax fraud.",38

Reporting incentives for those in possession of information otherwise difficult to obtain have proven successful. In a June 2006 report, the U.S. Treasury expressed that investigations based on the IRS whistleblower program were more effective and efficient in detecting tax noncompliance

34. Id. § 7623(b)(3) (emphasis added).

35. Davis-Nozemack \& Webber, supra note 16, at 81 (citing Letter from Jessica Radack, Dr. Marsha Coleman-Adebayo \& Gina Green to Douglas Shulman, Comm'r, Internal Revenue $\quad$ Serv., 3 (Aug. 3 10, 2011), http://www.grassley.senate.gov/about/upload/PlannedandInitiated Letter.pdf [hereinafter Radack Letter]). In this letter, Radack of the Government Accountability Project, ColemanAdebayo of the No FEAR Coalition, and Green of the National Whistleblowers Center wrote to the IRS Commissioner expressing their concern that the Internal Revenue Manual's interpretation of "planned and initiated" for purposes of considering a reduced bounty "depart[s] significantly from the traditional understanding of the planned and initiated limitation for [other] whistleblower awards as reflected in Congressional intent, the caselaw and the clear language of the statute.” Radack Letter, supra, at 1.

36. Robert W. Wood, Even Tax Cheats Can Claim IRS Whistleblower Rewards, BloOMBerg BNA TAX \& ACCOUNTING CENTER, Nov. 16, 2012, http://www.bna.com/eventax-cheats-n17179870951.

37. See Robert E. McKenzie, New Law Raises the Financial Incentive for Turning in Tax Cheats, 79 Practical Tax Strategies 40, 41 (2007) (discussing the compensation of whistleblowers under federal law).

38. Davis-Nozemack \& Webber, supra note 16 , at 82. 
than the IRS's primary method of selecting tax returns for further scrutiny. ${ }^{39}$ Statistics show that the revised IRS whistleblower program has indeed brought in more tips. Within the first twelve months of the amended program, the IRS received 116 submissions alleging more than \$2 million in tax violations, ${ }^{40}$ and an aggregate of 1,578 submissions by the end of fiscal year 2013. ${ }^{41}$

The SEC whistleblower program has been similarly successful since the Dodd-Frank amendments. The SEC has noted that it receives dozens of useful, high-quality tips per week. ${ }^{42}$ The SEC has described fiscal year 2014 as "historic," awarding individuals more whistleblower awards than in all prior years combined, including the largest award to date: \$30 million. ${ }^{43}$ The number of whistleblower tips that the SEC received in 2014 increased by approximately 20 percent in the last two years to a total of 3,620 . $^{44}$ The SEC noted that the recipients of whistleblower awards each provided valuable information that was specific, credible, and timely, identifying particular individuals involved in the fraud and specific documents or transactions substantiating the allegations that led to successful SEC enforcement actions. ${ }^{45}$

\section{B. Dodd-Frank Introduces a Bounty Model}

The current SEC whistleblower program was enacted in 2010

39. McKenzie, supra note 37 , at 42 .

40. See John Ashcroft, Catherine Hanaway \& Claudia L. Oñate Greim, Whistleblowers Cash In, Unwary Corporations Pay, 40 Hofstra L. Rev. 367, 378-79 (2011) (discussing the efficacy of the SEC's whistleblower program); see also News Release IR-2007-201, Internal Revenue Service, Procedure Unveiled for Reporting Violations of the Tax Law, Making Reward Claims, (Dec. 19, 2007), http://www.irs.gov/uac/Procedure-Unveiled-forReporting-Violations-of-the-Tax-Law,--Making-Reward-Claims (noting that since the 2006 amendments, "informants have come forward with information on alleged tax noncompliance amounting to tens of millions of dollars, and in some cases hundreds of millions of dollars.”).

41. See Internal Revenue Serv., Fiscal Year 2013 Report to the Congress on THE USE OF SECTION 7623 (2013), available at http://www.irs.gov/pub/whistleblower/ Whistleblower_Annual_report_FY_13_3_7_14_52549.pdf (discussing the policy ramifications of recently implemented whistleblower provisions).

42. See Ben Protess \& Nathaniel Popper, Hazy Future for Thriving S.E.C. WhistleBlower Effort, N.Y. Times, Apr. 23, 2013, at B1, http://dealbook.nytimes.com/2013/04/23/ hazy-future-for-s-e-c-s-whistle-blower-office/?_r=0 (noting the effectiveness of whistleblowers in enforcing SEC rules).

43. See SEC. \& EXCH. COMM'N, 2014 AnNuAl Report ON THE DodD-Frank WHISTLEBLOWER PROGRAM (2014), available at http://www.sec.gov/about/ offices/owb/annual-report-2014.pdf (discussing whistleblower tips and incentives in fiscal year 2014).

44. Id. at 3.

45. Id. at 16 . 
pursuant to the Dodd-Frank Act, a sweeping piece of legislation aimed at "promot[ing] the financial stability of the United States by improving accountability and transparency in the financial system ...."46 In addition to implementing a myriad of financial regulatory reforms, Dodd-Frank created a robust whistleblower program intended to promote the receipt of information pertaining to violations of securities laws. ${ }^{47}$ Section 922 of Dodd-Frank amends the Securities Exchange Act of 1934 by including a new section 21F, "Securities Whistleblower Incentives and Protection," 48 which improves the whistleblower retaliation protections of the SarbanesOxley Act of 2002 and creates a new bounty program requiring the SEC to pay whistleblowers who provide "original information" 49 regarding a violation of the federal securities laws. ${ }^{50}$ If the SEC is successful in an enforcement action based on this information, it:

[S]hall pay an award or awards to 1 or more whistleblowers who voluntarily provided original information to the [SEC] that led to the successful enforcement of the covered... action, in an aggregate amount equal to (A) not less than 10 percent, in total, of what has been collected of the monetary sanctions imposed in the action or related actions; and (B) not more than 30 percent, in total, of what has been collected of the monetary sanctions imposed in the action or related actions. ${ }^{51}$

The SEC determines the amount of the bounty in its discretion, taking into consideration the significance of the information and degree of assistance that the whistleblower has provided. ${ }^{52}$ Whistleblowers who are denied

46. H.R. REs. 4173, 111th Cong. (2010) (enacted).

47. See 15 U.S.C. § 78u-6 (2012 \& Supp. I 2013) (stipulating the incentives and protections afforded to whistleblowers).

48. 17 C.F.R. § 240.21F-1 (2014).

49. Id. § 240.21F-4(b). "Original” information is (i) derived from independent knowledge or independent analysis; (ii) not already known to the SEC from another source; (iii) not exclusively derived from an allegation made in a judicial or administrative hearing or governmental report or investigation; and (iv) provided to the SEC for the first time after July 21, 2010 (Dodd-Frank's enactment). Id.

50. See 17 C.F.R. $\S \S 240.21 \mathrm{~F}-1,240.21 \mathrm{~F}-2$ (stipulating compensation for whistleblowers); see also S. ReP. No. 111-176, at 110-11 (2010) (recommending the passage of the Dodd-Frank bill, the Senate Committee on Banking, Housing, and Urban Affairs noted that the new whistleblower program "aims to motivate those with inside knowledge to come forward and assist the Government to identify and prosecute persons who have violated securities laws and recover money for victims of financial fraud.”).

51. 15 U.S.C. § 78u-6(b).

52. See id. § 78u-6(c) (stipulating the terms of whistleblower awards). 
bounties can appeal their denial in federal court. ${ }^{53}$

The legislative history of Dodd-Frank reveals that the SEC whistleblower program was modeled after the 2006 amendments to the IRS whistleblower program. ${ }^{54}$ In a Senate Report examining Dodd-Frank, the Senate Committee on Banking, Housing, and Urban Affairs recognized the invaluable contributions that whistleblower tips provide, citing statistics that such tips have "detected $54.1 \%$ of uncovered fraud schemes in public companies" while external auditors and SEC exam teams detected only $4.1 \%$ of fraud schemes, making whistleblower tips "13 times more effective than external audits ...."55 The Committee also recognized that a whistleblower has a "difficult choice between telling the truth and the risk of committing 'career suicide,"” thereby supporting the new bounty structure as an appropriate reward to incentivize whistleblowers. ${ }^{56}$ Noting that the SEC whistleblower program is modeled after the amended IRS program, the Committee expressed the opinion that "[t]he reformed IRS program, which, too, has a similar minimum-maximum award levels and an appeals process, is credited to have reinvigorated the earlier, largely ineffective, IRS Whistleblower Program." ${ }^{57}$ The "critical component" of offering bounties to whistleblowers "is the minimum payout that any individual could look towards in determining whether to take the enormous risk of blowing the whistle in calling attention to fraud." 58

Despite being based on the IRS model, the SEC whistleblower program differs significantly as to the availability of bounties for culpable whistleblowers convicted of criminal activity related to the underlying action for which they are reporting. While the SEC will also reward a culpable whistleblower, it will not reward one who is convicted of the underlying crime. ${ }^{59}$ Section 78u-6(c)(2)(B) of Dodd-Frank states that "no award ... shall be made... to any whistleblower who is convicted of a

53. See id. § 78u-6(b)(2)(f) (discussing the appeals process for whistleblowers).

54. See S. REP. No. 111-176, at 110-11 (discussing the development of the IRS whistleblower program).

55. Id. at 110 (citing testimony for the Senate Banking Committee by Certified Fraud Examiner and Madoff whistleblower Harry Markopolos).

56. Id. at 111 .

57. Id.

58. Id.

59. See Heidi L. Hansberry, Comment, In Spite of Its Good Intentions, the Dodd-Frank Act Has Created an FCPA Monster, 102 J. CRIM. L. \& CRIMinology 195, 211 (2012) (recognizing that Dodd-Frank "draws a distinction between a cooperating informant who is convicted of a crime and a whistleblower.”); see also Richard F. Albert, Would \$104 Million IRS Whistleblower Get Stiffed under Dodd-Frank?, FORBES (Sept. 19, 2012), http://www.forbes.com/sites/insider/2012/09/19/would-104-million-irs-whistleblower-getstiffed-under-dodd-frank/ (noting that Bradley Birkenfeld would not have been granted an award if he provided information about corporate securities fraud instead of tax fraud). 
criminal violation related to the judicial or administrative action for which the whistleblower otherwise could receive an award ...." ${ }^{60}$ Although not included on the face of the statute itself, a variation of the "planning and initiating" language of the IRC is codified in the final SEC rules that implement Dodd-Frank, but only with respect to how the \$1 million threshold is determined. ${ }^{61}$ In determining whether the $\$ 1$ million level has been met for the underlying action, which is a prerequisite of eligibility for a bounty, the SEC will not take into account any monetary sanctions that the whistleblower is required to pay due to also being at fault. ${ }^{62}$ In addition, the SEC will not take into account any monetary sanctions ordered against an entity for conduct that the whistleblower directed, planned, or initiated. ${ }^{63}$ The SEC has expressed that the purpose of this provision "is to prevent wrongdoers from benefitting by, in effect, blowing the whistle on themselves." ${ }^{4}$ Therefore, the SEC uses a variation of the "planning and initiating" language found in the IRC not for the purpose of reducing the bounty, but to determine eligibility for the bounty itself. ${ }^{65}$

The SEC whistleblower program and the qui tam program of the False Claims Act, which will be explored further in Section II of this Article, resemble each other in that both deny rewards to whistleblowers who are convicted of any criminal conduct in connection with the underlying action. The IRS takes a broader approach to eligibility by making rewards available for convicted criminals as long as they have not "planned and initiated" the misconduct. ${ }^{66}$ These nuances have a significant practical effect. If Bradley Birkenfeld had blown the whistle on a violation of the securities laws rather than on tax evasion, he would not have been eligible for a bounty.

60. 15 U.S.C. § 78u-6(c)(2)(B) (2012 \& Supp. I 2013).

61. See 17 C.F.R. $\S 240.21 \mathrm{~F}-16$ (noting that whistleblowers who direct, plan, or initiate the conduct are limited in their awards).

62. Id.

63. Id. (emphasis added). This part of the rules also reads:

Similarly, if the [SEC] determines that a whistleblower is eligible for an award, any amounts that the whistleblower or such an entity pay in sanctions as a result of the action or related actions will not be included within the calculation of the amounts collected for purposes of making payments.

Id.

64. Press Release No. 2011-116, Sec. \& Exch. Comm'n, SEC Adopts Rules to Establish Whistleblower Program (May 25, 2011), available at http://www.sec.gov/news/ press/2011/2011-116.htm.

65. Compare 15 U.S.C. § 78u-6(b) (2012 \& Supp. I 2013) (discussing eligibility for and payment of awards) and 31 U.S.C. $\S 3730$ (b) (2012 \& Supp. I 2013) (stipulating actions by private persons) with 26 U.S.C. § 7623(b) (2012 \& Supp. I 2013) (discussing awards for whistleblowers).

66. 26 U.S.C. § 7623(b)(3). 


\section{REWARDING CULPABLE WHISTLEBLOWERS}

\section{A. Bradley Birkenfeld's Bounty}

Bradley Birkenfeld was an American private banker at UBS's headquarters in Geneva, Switzerland who was employed to advise United States taxpayers holding UBS accounts abroad. ${ }^{67}$ Birkenfeld, a Massachusetts native who studied banking at the American Graduate School of Business in Switzerland, worked five years for UBS in this capacity. ${ }^{68}$ Based in UBS's Global Wealth Management International \& Switzerland unit, Birkenfeld's primary duty was to acquire and develop new U.S. clients, which he accomplished by traveling to the U.S. on a quarterly basis. $^{69}$ Rather than conducting operations that were legal, Birkenfeld found himself in the midst of a major tax evasion scheme facilitated by UBS that helped U.S. taxpayers hide their assets in offshore accounts held by sham entities in Switzerland. ${ }^{70}$ UBS collaborated with U.S. taxpayers to prepare false IRS forms, giving the appearance that nonU.S. taxpayers owned the accounts, thereby aiding 19,000 clients in avoiding tax liabilities of about $\$ 19$ billion. $^{71}$ UBS trained its bankers, including Birkenfeld, to falsely state on customs forms upon arrival in the U.S. that they were traveling for pleasure instead of business and to carry encrypted laptop computers holding the portfolios of clients to avoid detection. ${ }^{72}$ Aware of the illegal scheme, Birkenfeld participated in the tax fraud by recruiting U.S. clients in this manner, helping them hide their

67. See John C. McDougal, The UBS “John Doe” Summons, in 2008 ALI-ABA Course of Study: International Trust \& Estate Planning 931, 962 (asserting that UBS is a bank headquartered in Switzerland which maintains branches throughout the United States, "provid[ing] a comprehensive range of products and services, individually tailored for wealthy and affluent clients around the world.”). McDougal conducted an interview with Bradley Birkenfeld on October 12, 2007 regarding Birkenfeld's practices as a U.S. tax advisor in Switzerland. Id.

68. See David Kocieniewski, Whistle-Blower Awarded \$104 Million by I.R.S., N.Y. TIMES, Sept. 11, 2012, http://www.nytimes.com/2012/09/12/business/whistle-blowerawarded-104-million-by-irs.html (describing Birkenfeld's whistleblowing efforts).

69. Id.

70. See J. Richard Harvey, Jr., Offshore Accounts: Insider's Summary of FATCA and its Potential Future, 57 VILL. L. Rev. 471, 476 (2012) (discussing the UBS scandal and Birkenfeld's role).

71. McDougal, supra note 67, at 962-65; see 60 Minutes: Banking: A Crack in the Swiss Vault (CBS television broadcast Dec. 30, 2009), available at http://www.cbsnews.com/ news/banking-a-crack-in-the-swiss-vault [hereinafter 60 Minutes] (discussing the secretive world of Swiss banking).

72. McDougal, supra note 67, at 963. 
assets from the IRS, including sneaking diamonds into the U.S. in a toothpaste tube on one occasion. ${ }^{73}$

In 2007, while still working at UBS, Birkenfeld began disclosing information about the scheme directly to the Department of Justice. ${ }^{74} \mathrm{He}$ offered to wear a wire to record the conversations of high-level UBS executives in exchange for full immunity from criminal prosecution. ${ }^{75}$ To his dismay, Birkenfeld was denied immunity because he failed to disclose his relationship with his biggest client, Igor Olenicoff, a U.S. taxpayer and wealthy real estate developer for whom Birkenfeld helped hide \$200 million in offshore hidden accounts. ${ }^{76}$ In May 2008, U.S. authorities arrested Birkenfeld for conspiracy to commit tax fraud stemming from his involvement with Olenicoff. ${ }^{77}$ Birkenfeld pleaded guilty to these charges on June 19, 2008. After Birkenfeld was denied immunity, a lighter sentence, and postponement of prison, ${ }^{78}$ he was sentenced to forty months in prison for his involvement in the tax evasion scheme. ${ }^{79}$

Birkenfeld's information as a whistleblower proved monumentally important in uncovering the specific details that led to an investigation of UBS by the Department of Justice. This information allowed the U.S. to penetrate Swiss banking secrecy laws and recover billions of dollars in

73. See Laura Saunders \& Robin Sidel, Whistleblower Gets \$104 Million, WALL ST. J., Sept. 11, 2012, http://online.wsj.com/news/articles/SB10000872396390444017504577645 412614237708 (discussing Birkenfeld's whistleblower award).

74. Harvey, supra note 70, at 476.

75. 60 Minutes, supra note 71 .

76. Id.; see Harvey, supra note 70 , at 476.

77. McDougal, supra note 67, at 962, 964-65. Birkenfeld later revealed that Olenicoff formed a Bahamian corporation with the assistance of UBS and completed a fraudulent IRS form that made it appear as if the corporation was actually the beneficial owner of his offshore UBS account. Id. at 963-64. Olenicoff then transferred \$60 million and a 147-foot yacht to the fake corporation and other sham entities, allowing him to "refrain from reporting the income secure in the knowledge that UBS would maintain the traditional secrecy of Swiss accounts.” Id. at 965. Olenicoff pleaded guilty to filing false tax returns in December of 2007. Id.; see Spencer Daly, Secrecy in Limbo: What the Most Recent Settlement with the IRS Means for UBS and the Rest of the Swiss Banking Industry, $10 \mathrm{~J}$. INT'L. Bus. \& L. 133, 146 (2011) (discussing Olenicoff's fraudulent activity).

78. See Press Release, Saul Ewing LLP, IRS Whistleblower Claims Increase After Whistleblower Convicted in Tax Scheme Receives Record-Setting \$104 Million Award (Nov. 1 2012), http://www.saul.com/publications-alerts-963.html (“[P]rosecutors opted to charge [Birkenfeld] with conspiracy to evade taxes due to his failure to fully disclose his own involvement in the fraud.”); see also Bruce Zagaris, IRS Pays Felon Birkenfeld \$104 Million as Whistleblower for UBS Case, 28 INT'L ENFORCEMENT L. REP. 391 (2012) (discussing Birkenfeld's whistleblower award).

79. See Curt Anderson, Bradley Birkenfeld: UBS Informant to Begin Prison Sentence Friday, Huffington Post, Mar. 18, 2010, http://www.huffingtonpost.com/2010/01/04/ bradley-birkenfeld-ubs-in_n_410753.html (discussing Birkenfeld’s prison sentence). 
unpaid taxes. ${ }^{80}$ Birkenfeld assisted the United States by providing internal UBS documents and information pertaining to the countless transactions with U.S. clients that were deeply concealed in Swiss vaults. ${ }^{81}$ Birkenfeld's information allowed the Department of Justice to garner enough evidence to file a petition in federal court in June 2008 requesting leave to file an IRS “John Doe' summons." ${ }^{22}$ This summons would require UBS to disclose the names of all of its U.S. clients who opened bank accounts in Switzerland that were undisclosed to the IRS-an endeavor "represent[ing] the first time that the United States ha[d] attempted to pierce Swiss bank secrecy by compelling a Swiss bank to name its U.S. clients." ${ }^{83}$ When UBS objected to the summons, citing Swiss bank secrecy law, the Swiss government intervened by filing an amicus brief arguing that the United States could obtain account-holder information only through a request under the 1996 U.S.-Swiss tax treaty. ${ }^{84}$ In August 2009, the U.S. government withdrew the John Doe summons, agreed with Switzerland to treat the request as occurring under the treaty, and signed a protocol amending the treaty. ${ }^{85}$ In February 2009, UBS signed a deferred prosecution agreement with the Department of Justice pursuant to which it was required to "provide the U.S. government with the names of 200 to 300 U.S. clients of [its] cross-border business, exit the business of providing banking services to U.S. clients with undeclared accounts, and pay a total of $\$ 780$ million in fines and penalties." ${ }^{\prime 86}$

Shortly thereafter, the IRS launched a voluntary disclosure initiative for offshore tax evasion, which required participating taxpayers to pay taxes and interest due on Swiss accounts for the previous six years and disclose information about their foreign accounts. ${ }^{87}$ This initiative, launched in 2009 and otherwise known as the Offshore Voluntary Disclosure Initiative or “OVDI”, was a variant of a longstanding initiative that the IRS already had in place to promote voluntary tax disclosures, but introduced more formal procedures and rules. ${ }^{88}$ The OVDI proved instrumental in prompting taxpayers to come forward and was:

80. 60 Minutes, supra note 71 .

81. Id.

82. Symposium, The Use of Voluntary Disclosure Initiatives in the Battle Against Offshore Tax Evasion, 57 VILL. L. REV. 499, 509 (2012).

83. Id.

84. Id.

85. Id.

86. Laura Szarmach, Note, Piercing the Veil of Bank Secrecy? Assessing the United States' Settlement in UBS Case, 43 CoRnELl InT'L L.J. 409, 411 (2010) (citing Deferred Prosecution Agreement, Exhibit C at 3-4, United States v. UBS AG, No. 09-60033 (S.D. Fla. Feb. 19, 2009)).

87. The Use of Voluntary Disclosure Initiatives, supra note 82, at 510.

88. See Paul Marcotte, IRS Winning Game of Offshore Hide and Seek, 46 MD. B.J. 4, 7 
[T]imed to profit from the publicity about Birkenfeld and UBS: 'Following the announcement in May 2008 that the Justice Department had indicted former UBS banker Bradley Birkenfeld, the IRS voluntary disclosure program saw a dramatic rise in taxpayers coming forward to turn over information on previously undisclosed Swiss bank accounts.' The 2009 initiative brought in about 15,000 disclosures-many times more than the approximately 1,000 that the IRS reportedly expected. In early 2012, the IRS reported that it had "collected \$3.4 billion so far from people who participated in the 2009 offshore program, reflecting closures of about 95 percent of the cases from the 2009 program." 89

Birkenfeld has been described "as the single most important informant in the U.S. probe of tax evasion and secrecy at UBS and other banks" and " "the goose that laid the golden eggs,", ${ }^{0}$ whose information "led to an investigation that has greatly diminished Switzerland's status as a secret haven for American tax cheats and allowed the Treasury to recover billions in unpaid taxes." 91

When Birkenfeld finished his prison term, the IRS awarded him what is believed to be "the largest-ever whistleblower payout to an individual." 92 On September 11, 2012, the IRS awarded Birkenfeld a bounty of \$104 million pursuant to the IRS whistleblower program. ${ }^{93}$ Birkenfeld was not disqualified from receiving the reward under the IRC because he was not

(2013) (discussing traditional internal voluntary disclosure practice and the transition to the more formalized practices under OVDI).

89. The Use of Voluntary Disclosure Initiatives, supra note 82, at 510 (citing David D. Stewart, IRS Voluntary Disclosure Program Gets High Marks from Practitioners, So Far, TAx Notes Today, Sept. 3, 2009, at 169-18; Shulman Addresses IRS's Strategic Priorities for the Future, TAx Notes Today, May 19, 2011, at 97-11; I.R.S. News Release IR-2012-5, Internal Revenue Serv., IRS Offshore Programs Produce \$4.4 Billion to Date for Nation’s Taxpayers; Offshore Voluntary Disclosure Program Reopen (Jan. 9, 2012), available at http://www.irs.gov/pub/irs-news/ir-12-005.pdf).

90. Andersen, supra note 79 (referencing comments of Birkenfeld's attorneys from the National Whistleblowers Center).

91. Kocieniewski, supra note 68; see Harvey, supra note 70, at 478 (noting that the Department of Justice began pursuing UBS on the basis of Birkenfeld's information); Bradley J. Bonti, Don't Tread on Me: Has the United States Government's Quest for Customer Records from UBS Sounded the Death Knell for Swiss Bank Secrecy Laws? 30 Nw. J. INT'L L. \& Bus. 1, 7-8 (2010) (“Information provided by Birkenfeld pointed prosecutors directly to UBS's banking operations in Switzerland.”).

92. Saunders \& Sidel, supra note 73.

93. Id.; see Saul Ewing LLP, supra note 78 (discussing Birkenfeld's \$104 million award for assisting the IRS). 
the "planne[r] and initiat[or]" of the fraud. ${ }^{94}$ Without offering insight as to how it made its determination, the IRS found that Birkenfeld's conduct did not amount to "planning and initiating," which caused one source to comment that " "[i]f Bradley Birkenfeld is award-eligible, your average tax director will have no problem overcoming the planned-and-initiated hurdle ....,"95 The IRS considered Birkenfeld to have been a low-level employee, "intimating that those higher up planned or initiated the scheme." 96 Although Birkenfeld was deemed not to be a planner or initiator of the tax fraud scheme, he was clearly not innocent. Aware of the illegality of UBS's direction, Birkenfeld proceeded to assist U.S. taxpayers in hiding their assets, including concealment of \$200 million of Igor Olenicoff's assets, his largest client. ${ }^{97}$

Significant public attention resulted from Birkenfeld's receipt of a $\$ 104$ million bounty, ${ }^{98}$ creating concerns among many that depicting "a criminal-turned-whistleblower" as a hero could negatively affect the public's perception of the role that whistleblowers play in society. ${ }^{99}$ One commentator described Birkenfeld's bounty as "'sordidness piled on sordidness," "100 responding to Birkenfeld's statement of "I'm the most famous whistleblower in the history of the world. It's a question of doing the right thing, and that's what I did" with "[w]hat would have been right was not participating in tax evasion in the first place."101

94. Pat Dulnier, UBS Whistleblower May Be Ineligible to Receive Reward Because of Dodd-Frank, BANK CREDIT NEws (Sept. 20, 2012), http://bankcreditnews.com/news/ubswhistleblower-may-be-ineligible-to-receive-reward-because-of-dodd-frank/5362.

95. Jeremiah Coder, IRS Pays Birkenfeld \$104 Million Whistleblower Award, TAX Notes TODAY (Sept. 1, 2012), http://www.tax-whistleblower.com/articles/IRS-PaysBirkenfeld-104-Million-Whistleblower-Award.pdf (citing Gregory S. Lyman of the Ferrero Law Firm); see Jack Townsend, Birkenfeld Gets \$104 Million Whistleblower Award, FeD. TAX CRIMES BlOG (Sept. 11, 2012, 1:22 PM), http://federaltaxcrimes.blogspot.com/ 2012/09/birkenfeld-gets-104-million.html (claiming that the award to Birkenfeld indicated the IRS's willingness to use information that violates foreign (Swiss) law in order to collect revenue).

96. Coder, supra note 95 (citing Barbara T. Kaplan of Greenberg Traurig LLP).

97. Ken Stier, Why Is the UBS Whistleblower Headed to Prison?, Time (Oct. 6, 2009), http://content.time.com/time/business/article/0,8599,1928897,00.html.

98. See Orly Lobel, Linking Prevention, Detection, and Whistleblowing: Principles for Designing Effective Reporting Systems, 54 S. TEx. L. REV. 37, 38 (2012) (noting that the $\$ 104$ million reward received substantial attention because of the size and surrounding circumstances).

99. Id. at 39.

100. Id. (quoting Holman W. Jenkins, Jr., Bradley Birkenfeld, Hero of Tax Reform, WALL ST. J., Sept. 15-16, 2012, at A13, available at http://online.wsj.com/news/articles/ SB10000872396390444023704577651231299649806).

101. Jenkins, supra note 100. 


\section{B. Should the Law Allow Culpable Whistleblowers to Be Rewarded?}

The story of Bradley Birkenfeld demonstrates the controversy surrounding the practice of allowing culpable whistleblowers to receive bounties, which is exacerbated in instances involving criminally-convicted whistleblowers. "Depending on your point of view, [Birkenfeld] is either a felon who was complicit in the crime he reported and does not deserve his reward or he is a new type of whistle-blower-one with knowledge of a complicated crime that came from being a part of it."102 The SEC has recognized that "sometimes we need people with dirty hands to point us in the right direction. It is not necessarily a good feeling for everyone, but sometimes it is necessary." 103

As a basic premise, rewarding whistleblowers with unclean hands provides value to the government, as was recognized by Congress when it enacted the qui tam program and subsequently the IRS and SEC whistleblower programs. The qui tam program of the False Claims Act ("FCA"), the statute upon which the 2006 IRC amendments were modeled, ${ }^{104}$ was the first to establish a bounty system and is often referred to as the "'gold standard' of whistleblower protection and bounty rewards.” 105 Under the FCA, private citizens, known as relators, may bring a "qui tam" 106 civil action on behalf of the United States against individuals who defraud the federal government by committing acts such as submitting

102. Paul Sullivan, The Price Whistle-Blowers Pay for Secrets, N.Y. TIMES, Sept. 22, 2012, at B5, available at http:/www.nytimes.com/2012/09/22/your-money/for-whistleblowers-consider-the-risks-wealth-matters.html?pagewanted=all\&_r=0.

103. Joe Mont, SEC's Whistleblower Bounties Will Be Awarded Subjectively, COMPLiANCE WeEK (June 6, 2012), http://www.complianceweek.com/secs-whistleblowerbounties-will-be-awarded-subjectively/article/244605/ (citing the SEC); see Robert Howse \& Ronald J. Daniels, Rewarding Whistleblowers: The Costs and Benefits of an IncentiveBased Compliance Strategy, in Corporate DeCISION-MAKING IN CANADA 525, 538 (Ronald J. Daniels \& Randall Morck eds., 1995) (noting that “[a] special difficulty is apparent when a whistleblower is involved in the wrongdoing she has reported, either through complicity or through active initiative.”).

104. Radack Letter, supra note 35, at 1; Michelle M. Kwon, Whistling Dixie About the IRS Whistleblower Program Thanks to the IRC Confidentiality Restrictions, 29 VA. TAX REV. 447, 457 (2010); Feldman \& Lobel, supra note 1, at 1168.

105. Rapp, supra note 6 , at 76 (noting that although one scholar has described the Sarbanes-Oxley Act as the gold standard of whistleblower protection, most research would support the FCA as such).

106. "Qui tam" is a Latin term that is short for a phrase that translates into "who as well for the king as for himself sues in this matter." "Heather Elliott, Congress's Inability to Solve Standing Problems, 91 B.U. L. ReV. 159, 196 n.219 (2011); see generally Patrick A. Barthle II, Note, Whistling Rogues: A Comparative Analysis of the Dodd-Frank Whistleblower Bounty Program, 69 WASH. \& LEE. L. REV. 1201, 1217 (2012) (noting that qui tam provisions were popular in England at the time the United States was founded). 
false claims for payment to the federal government, knowingly using false statements to decrease an obligation to pay money to the government, or inducing the payment of a false claim. ${ }^{107}$ The qui tam plaintiff brings the action in the name of the U.S. Government by filing a complaint in federal district court, at which point the federal government has sixty days to intervene in the lawsuit; if the government declines to intervene, the qui tam plaintiff may proceed with the lawsuit. ${ }^{108}$ The Department of Justice ("DOJ") oversees these lawsuits as the actual entity that intervenes in the qui tam action, providing a "gatekeeper" role in which the DOJ may control the prosecution or dismiss it entirely. ${ }^{109}$ The FCA, which one scholar has described as "the lodestar of private enforcement of public law," " makes bounties available to a qui tam plaintiff. If the government proceeds with the action, the qui tam plaintiff may receive fifteen to twenty-five percent of the proceeds of the action or settlement of the claim, depending upon the extent to which the person substantially contributed to the prosecution of the action, or between twenty-five to thirty percent if the government does not proceed with the action. ${ }^{111}$

The FCA originated during the Civil War when Congress was receiving reports of misappropriation of money spent to assist the war effort by government suppliers that:

'accepted almost every offer and paid almost any price for [war] commodities, regardless of character, quality or quantity .... For sugar [the government] often got sand; for coffee, rye; for leather, something no better than brown paper; for sound horses and mules, spavined beasts and dying donkeys . . . ,112

107. 31 U.S.C. § 3730(b) (2012 \& Supp. I 2013); Kwon, supra note 104, at 457; Dennis J. Ventry, Jr., Whistleblowers and Qui Tam for Tax, 61 TAX LAW. 357, 368 (2008).

108. Kwon, supra note 104, at 458 ("If the government intervenes [in the qui tam action], it has primary responsibility for prosecuting the action, but the qui tam plaintiff has the right to continue to be a party.” (citing 31 U.S.C. § 3730(c))).

109. David Freeman Engstrom, Public Regulation of Private Enforcement: Empirical Analysis of DOJ Oversight of Qui Tam Litigation under the False Claims Act, 107 Nw. U. L. REV. 1690, 1710-12 (2013). As Engstrom's research reveals, DOJ decision-making in qui tam litigation is controversial, as it is often guided by strategic and non-merit-based factors, prompting the need for an examination of judicial deference to such decisions. Id. at 174950.

110. Ventry, supra note 107 , at 368.

111. § 3730(d)(1); see id. (noting that there is no absolute dollar cap on the amount of the bounty that the qui tam plaintiff can receive and reasonable expenses are also reimbursable); see also Joel D. Hesch, The False Claims Act Creates a "Zone of Protection" that Bars Suits Against Employees Who Report Fraud Against the Government, 62 DRAKE L. REv. 361 (2014) (discussing the key False Claims Act provisions that promote federal interests in recruiting and protecting qui tam whistleblowers).

112. Michael Neal, Securities Whistleblowing under Dodd-Frank: Neglecting the 
This misappropriation prompted the introduction of the FCA bill in 1863 to prevent and punish frauds committed against the U.S. government. ${ }^{113}$ The FCA is premised on the theory that it takes "a rogue to catch a rogue."114 The notion that complicit informants should be granted rewards for their information is rooted in motivating co-conspirators to provide information about each other. ${ }^{115}$ "The overriding theme of the [FCA] is virtually to deputize an army of insiders to uncover, inform, and pursue those government contractors who knowingly cheat in their agreements with the government." 116 The receipt of information from people on the inside is tremendously valuable, as wrongdoing often "takes place in the shadows [and] may never be visible to anyone but the immediate actors." 117 The idea behind this theory, "based on experience as old as modern civilization," is that one of the most effective ways to detect fraud is to make its perpetrators liable to the action of a private person (the relator) acting "under the strong stimulus of personal ill will or the hope of gain."118

In enacting the FCA, Congress recognized the difficulties inherent in obtaining information from insiders or participants, who commonly feel that they have little to gain from reporting on fraudulent behavior and would more likely do so if financially rewarded. ${ }^{119}$ The primary goal of the

Power of "Enterprising Privateers" in Favor of the "Slow-Going Public Vessel," 15 LEWIS \& Clark L. Rev. 1107, 1110 (2011) (citing Claire M. Sylvia, The False Claims Act: Fraud Against the Government $\S 2: 6$, at 42-43 (2010) (quoting 1 Fred Albert Shannon, The Organization and Administration of the Union ARMY 1861-1865, at 55-56, 58 (1928))).

113. James B. Helmer, Jr., False Claims Act: Incentivizing Integrity for 150 Years for Rogues, Privateers, Parasites, and Patriots, 81 U. Cin. L. REV. 1261, 1265 (2013) (citing Cong. Globe, 37Th Cong., 3D Sess. 955, at 348 (1863) (statement of Senator Henry Wilson)).

114. Id. at 1266 (citing Cong. Globe, 37TH Cong., 3D Sess. 955, at 348 (1863)

(statement of Senator Jacob M. Howard)). Senator Howard stated the following: [t]he bill offers, in short, a reward to the informer who comes into court and betrays his co-conspirator, if he be such . ... I have based the fourth, fifth, sixth, and seventh sections upon the old-fashioned idea of holding out a temptation, and 'setting a rogue to catch a rogue,' which is the safest and most expeditious Id. way I have ever discovered of bringing rogues to justice.

115. Id.

116. Id. at 1262 .

117. Daniel K. Tarullo, The Limits of Institutional Design: Implementing the OECD Anti-Bribery Convention, 44 VA. J. INT’L L. 665, 689 (2004).

118. Paul E. McGreal \& DeeDee Baba, Applying Coase to Qui Tam Actions Against the States, 77 Notre Dame L. Rev. 87, 123 (2001) (quoting United States v. Griswold, 24 F. 361, 366 (D. Or. 1885)).

119. J. Randy Beck, The False Claims Act and the English Eradication of Qui Tam Legislation, 86 N.C. L. REV. 539, 563 (2000). 
FCA is the receipt of valuable information, which is incentivized regardless of whether the whistleblower was personally involved in the wrongdoing. ${ }^{120}$ As Terry Dworkin and Elletta Callahan explain, "the FCA rewards a 'source' who comes forward with useful information, no matter whether his or her decision to report was based on greed, a risk/benefit analysis, conscience, or something else.”121

The policy rationale behind bounty rewards - even to those who are complicit-is to provide benefits to the whistleblower that outweigh the various costs of reporting information. ${ }^{122}$ Whistleblower scholars have widely noted the significant difficulties that whistleblowers face in deciding whether to come forward. Richard Moberly has expressed that "almost all the benefits of whistleblower disclosures go to people other than the whistleblower, while most of the costs fall on the individual whistleblower." 123 Geoffrey Rapp has noted that "[s]omeone with information about fraud, absent bounties, faces a set of values-related or ethical pressures to blow the whistle, a set of values-related or ethical pressures to remain silent, as well as a set of economic or pecuniary pressures to remain silent." ${ }^{124}$ When whistleblowers are themselves complicit, their incentives to report are likely to be even lower. In such cases, the cost-benefit scale of reporting is likely to be heavily tipped towards the cost end of the scale. ${ }^{125}$ Therefore, it may be argued that bounties become even more important in these circumstances.

120. Terry Morehead Dworkin \& Elletta Sangrey Callahan, Employee Disclosures to the Media: When Is a "Source" a "Sourcerer"?, 15 HASTINGS Comm. \& ENT. L.J. 357, 368-69 (1993).

121. Id. (noting that even a party who planned and initiated the wrongdoing can recover under the FCA as long as such person is not convicted of a crime arising therefrom).

122. See Geoffrey Christopher Rapp, States of Pay: Emerging Trends in State Whistleblower Bounty Schemes, 54 S. TEX. L. REV. 53, 59 (2012) (discussing the role of rewards in overcoming the concerns that cause potential whistleblowers to remain silent); see also Ashlin Aldinger, Comment, A Race to the IRS: Are Snitches and Criminals the New Business Model? 51 Hous. L. Rev. 913, 931 (2014) (discussing what motivates whistleblowers to come forward and the potential moral issues with offering bounties to incentivize individuals to report tax noncompliance).

123. Richard Moberly, Protecting Whistleblowers by Contract, 79 U. CoLO. L. ReV. 975, 980 (2008). He further posited that:

[s]ociety as a whole benefits from increased safety, better health, and more efficient law enforcement; shareholders benefit from increased transparency of corporate finances; and employees as a group benefit from improved working conditions. Whistleblowers, on the other hand, face significant retaliation, from isolation at work, to discharge, to physical violence.

Id. at $980-81$.

124. Rapp, supra note 122, at 59.

125. See Beck, supra note 119, at 563 (explaining that inside information about wrongdoing is difficult to obtain because a person who participates in misconduct may have very little to gain and much to lose from exposing the fraudulent behavior). 
As discussed, the legacy of the FCA creates an "innate conflict of using a 'rogue' to catch a rogue .... [Whistleblower bounty] programs use informants they perhaps should not trust to catch cheats they do not trust. And therein lies the conflict." ${ }^{, 26}$ However, "[w]histleblowers, culpable or not, are typically the only individuals who can (and often do) expose wrongdoing. Without whistleblowers, the scandals they report on may never be known." 127 At the same time, there are concerns that providing bounties to culpable whistleblowers will actually encourage misconduct and may create an incentive to involve other employees in the wrongdoing. ${ }^{128}$

The comments that the SEC received as part of its rulemaking process to implement the whistleblower section of Dodd-Frank provide a good example of the spectrum of perspectives pertaining to the issue of rewarding culpable whistleblowers. Public policy considerations and the proper balance between rewarding culpable whistleblowers for their information and avoiding their reporting merely for bounty purposes must be thoroughly considered in implementing any bounty structure. The SEC received over 240 comment letters and approximately 1,300 form letters from individuals, whistleblower advocacy groups, companies, law firms, and academics critiquing and supporting certain aspects of the proposed rules implementing Dodd-Frank, ${ }^{129}$ including the issue of whether awards should be available to culpable whistleblowers. ${ }^{130}$

Several commentators recommended that the definition of "whistleblower" be limited to cover only those individuals who did not participate at all in the violations, ${ }^{131}$ thus excluding anyone with unclean hands. Others commented that culpable whistleblowers should still receive awards but on a reduced level as not to create incentives for individuals to engage in wrongdoing. ${ }^{132}$ Many commentators were opposed to rules that

126. Barthle, supra note 106, at 1202.

127. Dylan Blaylock, 'Culpable' Whistleblowers Deserve Leniency, Gov'T ACCOUnTABILITY PROJECT (July 8, 2011), http://gaproject.nonprofitsoapbox.com/blog/ $31 / 1252$.

128. Howse \& Daniels, supra note 103, at 538.

129. Securities Whistleblower Incentives and Protections, 76 Fed. Reg. 34,300, 34,30001 (June 13, 2011) [hereinafter Final SEC Rules].

130. Id. at 34,300. Commentators also expressed views on the proposed exclusions from award eligibility for certain individuals, the procedures for making a claim for a bounty, and the application of the anti-retaliation provision. Id.

131. Id. at 34,302 (citing comment letters from Americans for Limited Gov't; Ryder Sys., Inc.; Fin. Serv. Inst., Inc.; U.S. Chamber of Commerce; Verizon; and White \& Case LLP).

132. Id. at 34,330 (citing comment letters from Connolly \& Finkel, Target, SIFMA, Bus. Roundtable, Washington Legal Found., Morgan Lewis, Fin. Serv. Roundtable, Soc’y of Corporate Sec'ys, Wells Fargo, Trace, Alcoa Grp., Oppenheimer Funds, Ass'n of 
would exclude culpable whistleblowers completely from eligibility, arguing that insiders possess crucial knowledge and information about fraud and will be dissuaded from coming forward without the incentive that a bounty offers. ${ }^{133}$ The Auditing Standards Committee of the American Accounting Association was opposed to the SEC's inquiry as to whether it should define "whistleblower" as an individual who provides information about potential securities law violations "by another person" so as to avoid rewarding whistleblowers for their own misconduct. ${ }^{134}$ The Auditing Standards Committee argued that limiting the definition of "whistleblower" as such may restrict those who are "tangentially involved" from making a report, which may include instances in which people believe they have participated in wrongdoing because they did not immediately report their observance of it or those who cooperate with wrongdoers under duress or coercion. ${ }^{135}$ Attorneys with experience representing whistleblowers bringing qui tam actions under the False Claims Act echoed these sentiments, arguing that defining whistleblowers as such may bar them from reporting even if they had a low level of participation in the wrongdoing. ${ }^{136}$ Because insiders have "a first-hand view of the fraud, they are frequently the best sources of information in enforcement actions against companies and upper level management.”137

In contrast, some commentators-including the Securities Industry and Financial Markets Association, an organization representing securities firms, banks, and asset managers, Business Roundtable, an association of chief executive officers of major corporations, and OppenheimerFunds, Inc., a registered investment advisor-were in favor of defining a "whistleblower" as an individual who reports on violations committed by "another person." "138 These organizations argued that allowing individuals

Corporate Counsel, and the U.S. Chamber of Commerce Center for Capital Mkts. Competitiveness); see Hansberry, supra note 59 (arguing that Dodd-Frank over-incentivizes whistleblowers by providing rewards to culpable whistleblowers who may not be convicted).

133. Id. at 34,330-31 (citing comment letters from Auditing Standards Comm. of the Auditing Section of the Am. Accounting Ass'n, George Merkl and the Nat'l Whistleblower Ctr.).

134. Auditing Standards Comm. of Am. Accounting Ass'n, Comment Letter on File No. S7-33-10, SEC. \& EXCH. COMM'N, Dec. 17, 2010, available at http://www.sec.gov/ comments/s7-33-10/s73310-149.pdf.

135. Id.

136. Wu, Grohovsky \& Whipple; Vogel, Slade \& Goldstein; and Kenney \& McCafferty, Comment Letter on File No. S7-33-10, Sec. \& ExсH. Comm'N, Dec. 16, 2010, at 6, available at http://www.sec.gov/comments/s7-33-10/s73310-136.pdf.

137. Id.

138. SIFMA, Comment Letter on File No. S7-33-10, SEC. \& ExCH. COMM’N (Dec. 16, 2010), http://www.sec.gov/comments/s7-33-10/s73310-161.pdf; OppenheimerFunds, 
to profit while they also took part in the violations incentivizes misconduct and is contrary to the intent of Congress to reduce the overall number of violations of the law. ${ }^{139}$

In an effort to adhere to the language of the statute as enacted by Congress, the SEC included in its final rules the culpability of whistleblowers (who are not convicted) as a factor that may decrease a whistleblower's award percentage. ${ }^{140}$ For example, the SEC may decrease an award if the whistleblower played a significant role in the wrongdoing, acted with scienter, financially benefited from the violation, is a recidivist, or knowingly interfered with the SEC's investigation of the violation. ${ }^{141}$ The SEC will also consider the egregiousness of the underlying fraud committed by the whistleblower. ${ }^{142}$

In a separate section of the rules pertaining to awards for whistleblowers who engage in culpable conduct, the SEC emphasized that it would not include "any monetary sanctions that the whistleblower is ordered to pay, or that an entity is ordered to pay if the entity's liability is based substantially on conduct that the whistleblower directed, planned, or initiated" in the required \$1,000,000 threshold for an award. ${ }^{143}$ In adopting the final rules, the SEC noted that public comment largely opposed an outright exclusion of culpable whistleblowers because the information they provide is too valuable. ${ }^{144}$ Those in favor of awarding culpable whistleblowers also believed that bounties may actually deter future conduct because those who violate securities law would be aware of the possibility that a co-conspirator might turn against them and report the wrongdoing in search of a bounty. ${ }^{145}$

In adopting final rule 21F-16, the SEC stated:

[W]e do not believe that a per se exclusion for culpable whistleblowers is consistent with Section $21 \mathrm{~F}$ of the Exchange Act... the original Federal whistleblower statute-the False Claims Act-was premised on the notion that one effective way to bring about justice is to use a rogue to catch a rogue. This

Comment Letter on File No. S7-33-10, SEc. \& ExсH. Comm’n (Dec. 17, 2010), http://www.sec.gov/comments/s7-33-10/s73310-195.pdf.

139. Id.

140. Final SEC Rules, supra note 129, at 34,300, 34,331; 17 C.F.R. § 240.21F-6(b)(1) (2014).

141. Id. at 34,331; 17 C.F.R. § 240.21F-6(b)(1) (2014).

142. Id.

143. Id. at 34,349; 17 C.F.R. § 240.21F-16 (2014).

144. Id. at 34,349-50.

145. Id. ("[S]ecurities violators would know that they forever face an increased risk that one of their co-conspirators 'might turn state's evidence against them.'” (citation omitted)). 
basic law enforcement principle is especially true for sophisticated securities fraud schemes which can be difficult for law enforcement authorities to detect and prosecute without insider information and assistance from participants in the scheme or their coconspirators. ${ }^{146}$

At the same time, the SEC was sensitive to the fact that a failure to limit culpable whistleblowers' eligibility for awards could prompt public policy concerns. ${ }^{147}$ The SEC created a reasonable middle ground to this conflict by enacting final rules that incentivize less culpable individuals to come forward while limiting awards based on the culpable whistleblower's specific level of involvement.

The outright ban on rewarding whistleblowers convicted of criminal activity in the action for which they are reporting was never altered from Dodd-Frank's language as enacted by Congress during the SEC rulemaking process, and, in fact, was never discussed in the public comments. ${ }^{148}$ The legislative history of Dodd-Frank similarly lacks analysis as to the rationale behind denying convicts a bounty. Although impossible to pinpoint, this void may be best explained by the view that such a concept-allowing a convicted criminal to obtain a bounty-is morally reprehensible to many.

\section{CRITIQUE OF THE IRS MODEL}

\section{A. Immunity and Leniency}

The law has long recognized the "fundamental equitable principle" that criminals, who have either admitted to guilt during a plea bargain process or have been proven guilty beyond a reasonable doubt after trial, should not financially benefit from their actions. ${ }^{149}$ Case law stemming

146. Id. (emphasis in original) (footnote omitted) (noting that "[i]nsiders regularly provide law enforcement authorities with early and invaluable assistance in identifying the scope, participants, victims, and ill-gotten gains from these fraudulent schemes. Accordingly, culpable whistleblowers can enhance the [SEC]'s ability to detect violations of the Federal securities laws, increase the effectiveness and efficiency of the [SEC]'s investigations, and provide important evidence for the [SEC]'s enforcement actions.”).

147. Id.

148. See Final SEC Rules, supra note 129 (providing no explanation as to why convicted whistleblowers are denied a bounty).

149. Simon \& Schuster, Inc. v. Members of N.Y. State Crime Victims Bd., 502 U.S. 105, 119 (1991) (citing Children of Bedford v. Petromelis, 573 N.E.2d 541, 548 (N.Y. 1991)). In contexts beyond whistleblowing, these principles have prompted the enactment of laws like the "Son of Sam laws," which prevent criminals from earning a profit from the commercial sale of their crime stories. See Sarah N. Conde, Capote in the Jury Box: Analyzing the Ethics of Jurors Writing Books, 19 GeO. J. Legal Ethics 643, 655 (2006) 
from the nineteenth century highlights the public policy concerns associated with allowing wrongdoers to profit from their misdeeds:

No one shall be permitted to profit by his own fraud, or to take advantage of his own wrong, or to found any claim upon his own iniquity, or to acquire property by his own crime. These maxims are dictated by public policy, have their foundation in universal law administered in all civilized countries, and have nowhere been superseded by statutes. ${ }^{150}$

The IRS whistleblower program disregards these principles by allowing those whistleblowers who undergo a criminal prosecution and conviction to walk away from their prison time with money, excluding only those who planned and initiated the action. In this way, the IRS whistleblower program creates a risk that such a program may prompt the occurrence of the very behavior that it seeks to prevent. ${ }^{151}$

A more palatable alternative to the IRS's current treatment of convicted whistleblowers may be to offer immunity or leniency in lieu of a bounty to those whistleblowers who are facing criminal prosecution-an opportunity that is already in existence and is likely to suffice in incentivizing culpable whistleblowers to come forward. ${ }^{152}$ Cooperation by

(discussing the constitutional law implications of New York's "Son of Sam” law); Jessica Yager, Investigating New York's 2001 Son of Sam Law: Problems with the Recent Extension of Tort Liability for People Convicted of Crimes, 48 N.Y.L. SCH. L. REV. 433, 438 (2004) (outlining the history of New York's "Son of Sam" law). The sponsor of the original "Son of Sam law" bill described the need for the law as such: "[i]t is abhorrent to one's sense of justice and decency that an individual... can expect to receive large sums of money for his story once he is captured ....” Simon \& Schuster, 502 U.S. at 108 (quoting Memorandum of Sen. Emanuel R. Gold, reprinted in NeW YoRK StATe Legislative ANNUAL 1977, at 267).

150. Riggs v. Palmer, 22 N.E. 188, 190 (N.Y. 1889). Although Riggs and the Son of Sam laws were applied in the context of committing murder or causing physical injury to others, the basic premise of these words is a founding principle of the nation's legal system.

151. See Hansberry, supra note 59, at 211 (noting the potential dangers inherent in rewarding complicit behavior).

152. See Michael D. Silberfarb, Justifying Punishment for White-Collar Crime: A Utilitarian and Retributive Analysis of the Sarbanes-Oxley Act, 13 B.U. PUB. INT. L.J. 95, 113 n.125 (2003) (asserting that a Department of Justice Status Report on whistleblower leniency programs suggests that "over a five year period use of informants was five times more likely to be responsible for detecting and prosecuting cartels than any other tool used.”); Omari Scott Simmons \& James D. Dinnage, Innkeepers: A Unifying Theory of the In-House Counsel Role, 41 Seton Hall L. Rev. 77, 102 (2011) (noting that "[a] prime illustration" of incentives and immunities for whistleblowers is the antitrust arena in which a corporation that is the first to report illegal cartel behavior to the Department of Justice may avoid criminal liability); see also Charlotte Dennett, Closing the Impunity Gap: How Lawyers and Judges are Holding Higher-Ups Accountable, 37 VT. B.J. 32, 33 (2011) 
criminal defendants in exchange for leniency is one of the most pervasive tools used by the government in criminal law enforcement and has also gained popularity in regulatory settings in recent years. ${ }^{153}$

Miriam Baer has described the "Detection Effect" of cooperation, which enables the government to more successfully detect and prosecute wrongdoers, thereby creating a deterrent effect in a "rational violator" who faces an increased probability of getting caught. ${ }^{154}$ Cooperation allows the government to encourage defendants to proffer information at early stages of the investigation or prosecution, which may fill in holes in a case against a defendant, uncover new information about others involved, and provide insights about the defendant's bargaining position. ${ }^{155}$ As Baer notes, "[i]t is no secret that the unequal bargaining position between prosecutor and defense attorney serves as an information-forcing device,” which generally allows a prosecutor to "enjoy monopoly power over the cooperation process." leniency, since the government has the power to limit the amount of cooperation agreements that it offers to defendants. ${ }^{157}$ In some instances, the government may have a more difficult time unearthing the truth when cooperators provide inaccurate or false information, as defendants may be tempted to minimize their own culpability in the wrongdoing, omit information about prior criminal conduct, or falsely implicate others. ${ }^{158}$

For these reasons, the government denied Birkenfeld leniency and immunity. He was ultimately prosecuted because of his relationship with his largest client, wealthy real-estate developer Igor Olenicoff, who cooperated with the Department of Justice investigation and avoided jail time by paying $\$ 52$ million in fines and back taxes. ${ }^{159}$ Despite the immense amount of helpful information that Birkenfeld provided the government as a cooperator, he made one fatal mistake: failing to disclose his relationship with Olenicoff. ${ }^{160}$ As such, Birkenfeld was charged with conspiracy to commit tax fraud, to which he pled guilty. ${ }^{161}$ Thomas Perrelli, former

(noting that while high level officials who commit crimes are often granted immunity, whistleblowers are being prosecuted).

153. Miriam Hechler Baer, Cooperation's Cost, 88 Wash U. L. ReV., 903, 905-06 (2011).

154. See id. at 917 (describing how the "Detection Effect" may change the behavior of "rational violators").

155. Id. at 920 .

156. Id.

157. Id. at $920-21$.

158. See id. at 932-39 (discussing the aspects of cooperation that may reduce the overall “Detection Effect”).

159. 60 Minutes, supra note 71 , at $10: 16$.

160. Id.

161. Id. 
Associate Attorney General of the United States, commented that Birkenfeld would likely never have been prosecuted had he come forward from the beginning and told authorities of his relationship with Olenicoff. ${ }^{162}$ Ultimately it was claimed that Birkenfeld "had the last laugh," 163 as he was rewarded \$104 million upon his exit from prison"more than \$4,600 for every hour he spent in prison." 164 Birkenfeld's attorney remarked that "[t]he IRS reward will help undo the tremendous damage caused by the ill-conceived decision of the U.S. Department of Justice to . . . prosecute Mr. Birkenfeld.”165

In one of his media interviews, Birkenfeld consistently admitted that he was initially motivated to blow the whistle on UBS because of the desire for immunity. ${ }^{166}$ Birkenfeld claims that his motivations to inform governmental authorities of the tax fraud were mostly altruistic, as he willingly agreed to wear a wire to record conversations of his colleagues in exchange for full immunity for his participation in the fraud. ${ }^{167}$ In fact, nothing suggests that Birkenfeld's motivation was prompted by a potential bounty, as the IRS whistleblower program, although enacted in 2006, had a very slow start. ${ }^{168}$ The IRS was still implementing the law well into $2008,{ }^{169}$ and the first bounty granted under the 2006 amendments was not until fiscal year 2011. ${ }^{170}$

The impossibility of knowing what truly motivated Birkenfeld to come forward raises the question of whether would-be whistleblowers who

162. Id. at $10: 57$.

163. Id. at 12:30

164. Kocieniewski, supra note 68 .

165. Bittersweet Justice for Bradley Birkenfeld, EMPTYwHEEL (Sept. 11, 2012), http://www.emptywheel.net/2012/09/11/bittersweet-justice-for-bradley-birkenfeld (quoting Stephen Kohn); see Stier, supra note 97 (noting that whistleblowing can amount to "professional suicide" and financial rewards may compensate for this consequence); Jesselyn Radack, Government Missed Opportunities in UBS Whistleblower Case, Gov'T ACCOUNTABILITY PROJECT (Sept. 12, 2012), http://www.whistleblower.blog/42-2012/2234government-missed-opportunities-in-ubs-whistleblower-case (arguing that the IRS whistleblower program "should not be used to entrap whistleblowers into criminal prosecutions.”).

166. 60 Minutes, supra note 71 , at 4:26.

167. Id.

168. Birkenfeld's Bonanza, THE ECONOMIST (Sept. 11, 2012, 6:50 PM), http://www.economist.com/blogs/schumpeter/2012/09/whistleblowing.

169. Internal REVEnUe SERV., Whistleblower ANNUAL REPORT (2008), available at http://www.irs.gov/pub/whistleblower/whistleblower_annual_report.pdf.

170. Internal Revenue Serv., Fiscal Year 2012 RePORT to Congress 1 (2012), available at http://www.irs.gov/pub/whistleblower/2012\%20IRS\%20Annual\%20 Whistleblower\%20Report\%20to\%20Congress_mvw.pdf; Ryan Donmoyer, IRS Paid No Rewards in U.S. Whistleblower Program, BloOMBERG, Dec. 15, 2010, www.bloomberg.com/news/2010-12-15/irs-paid-no-rewards-to-informants-in-u-s-

whistleblower-program.html. 
are culpable would be more likely to choose a bounty over leniency or immunity. Although government authorities ultimately denied Birkenfeld immunity because of his failure to disclose his business relationship with Olenicoff, his story reveals that the availability of leniency or immunity to potential whistleblowers likely facing criminal prosecution may be enough to incentivize such persons to disclose wrongdoing. In fact, empirical legal research has proposed that the motivation of whistleblowers to come forward may be due to a personal desire for remediation. A novel empirical study by legal scholars Yuval Feldman and Orly Lobel measured the effects of different regulatory mechanisms, including monetary rewards, anti-retaliation rights, duties to report, and liability fines on the motivations of individuals to become whistleblowers. ${ }^{171}$ This research revealed that monetary rewards to induce whistleblowing frequently affect levels of reporting but identified an interesting distinction-that rewards like bounties may have a minimal effect on a person's motivation to blow the whistle when the action for which they are reporting is perceived as morally offensive, such as in instances of fraud. ${ }^{172}$ Feldman and Lobel's research determined that an individual's perception of the severity of the wrongdoing for which they are reporting has an impact on whether they will decide to ultimately report- - "the more outraged respondents feel about the illegal behavior, the more likely they are to report and to predict reporting by others." ${ }^{173}$

Comments as part of the SEC rulemaking process to implement DoddFrank explored the notion that culpable whistleblowers facing possible criminal prosecution already have incentives beyond financial awards to come forward. Some commentators opposed making bounties available to any whistleblower with unclean hands. ${ }^{174}$ Many commentators suggested that potential whistleblowers who are culpable are already incentivized to report their misconduct in return for leniency, ${ }^{175}$ including reduced sanctions or credit for cooperating ${ }^{176}$ and participating in cooperation or

171. Feldman \& Lobel, supra note 1.

172. Id. at 1200-03; see Dennis J. Ventry, Jr., Not Just Whistling Dixie: The Case for Tax Whistleblowers in the States, 59 VILL. L. REV. 425, 464 (2014) (describing a report of the Ethics Resource Center, which showed that whistleblowers are increasingly motivated to report if the misconduct is significant with potential harm to others).

173. Feldman \& Lobel, supra note 1, at 1192.

174. Davis Polk \& Wardwell LLP, Comment Letter on File No. S7-33-10, SEC. \& EXCH. Comm’N (Dec. 17, 2010), http://www.sec.gov/comments/s7-33-10/s73310-200.pdf.

175. Id.

176. Fin. Serv. Roundtable, Comment Letter on File No. S7-33-10, SEC. \& Exch. Comm’N (Dec. 17, 2010), http://www.sec.gov/comments/s7-33-10/s73310-191.pdf. 
voluntary disclosure programs that entities like the SEC and IRS already have in place. ${ }^{177}$

As it stands now, the SEC and IRS will not make amnesty available to culpable whistleblowers just because they have come forward with information. However, the SEC and IRS whistleblower programs recognize the valuable contributions that such persons offer, which both agencies consider when deciding whether to proceed with civil sanctions or criminal prosecutions. The SEC rules implementing Dodd-Frank express that " $\mathrm{t}$ ] he fact that [one] become[s] a whistleblower and assist[s] in [SEC] investigations and enforcement actions does not preclude the [SEC] from bringing an action against [the whistleblower] based upon [his/her] own conduct in connection with violations of the Federal securities laws." ${ }^{178}$ Despite the SEC's unwillingness to grant immunity to complicit whistleblowers, the SEC rules also state that it will take the whistleblower's cooperation into consideration in accordance with its Cooperation Policy, which was strengthened in 2010. ${ }^{179}$ The SEC's current Cooperation Policy attempts to reconcile the tension between holding culpable actors fully accountable for their misconduct while, at the same time, providing incentives for such persons to cooperate with law enforcement authorities. ${ }^{180}$ Adopted in the wake of the Bernie Madoff scandal, the SEC Cooperation Policy aims to incentivize individuals to come forward and cooperate with SEC investigations, which former SEC Enforcement Director Robert Khuzami called a potential "gamechanger” ${ }^{181}$ given the fraud that this policy is likely to uncover.

To determine whether leniency and a civil enforcement action under SEC policy is warranted, the SEC examines the level of assistance provided by the whistleblower, the importance of the underlying matter, the societal interest of holding culpable persons accountable for their misconduct, and the appropriateness of cooperation credit based upon the profile of the specific individual. ${ }^{182}$ The SEC offers leniency in various forms. Through a cooperation agreement, the Enforcement Division

177. See Ass'n of Corp. Counsel, Comment Letter on File No. S7-33-10, SEC. \& ExCH. Comm'N (Dec. 17, 2010), http://www.sec.gov/comments/s7-33-10/s73310-144.pdf (advocating for an SEC rule requiring the disclosure of conflicts of interest).

178. 17 C.F.R. § 240.21F-15 (2014).

179. Press Release, Sec. \& Exch. Comm’n, Policy Statement Concerning Cooperation by Individuals in its Investigations and Related Enforcement Actions (Jan. 19, 2010), available at http://www.sec.gov/rules/policy/2010/34-61340.pdf.

180. Id. at 3 .

181. Thomas A. Sporkin \& Pavitra Bacon, SEC Cooperation Is Still More Art Than Science, LAw360 (Jan. 23, 2014), http://www.law360.com/articles/501660/sec-cooperationis-still-more-art-than-science.

182. Id. 
recommends to the SEC that a cooperator should receive credit for cooperating in investigations if such person offers "substantial assistance" to SEC investigations and enforcement actions. ${ }^{183}$ The SEC may also offer deferred or non-prosecution agreements, or formal written agreements, in which it agrees not to carry out an enforcement action against a cooperator if such individual or company "agrees to cooperate fully and truthfully and to comply with certain reforms, controls and other undertakings." 184 The Cooperation Policy also now permits the SEC to make immunity requests to the Department of Justice to obtain testimony or witness cooperation from individuals like culpable whistleblowers who possess valuable information in exchange for protection against criminal prosecution. ${ }^{185}$ In cases when an individual asserts his or her Fifth Amendment privilege against self-incrimination, the SEC may seek statutory immunity to obtain a court order compelling an individual to testify, so long as such request is approved by the U.S. Attorney General, or letter immunity, which is conferred by agreement between the individual and a U.S. Attorney's Office. ${ }^{186}$ Both types of immunity prevent any statements or information to be used against the individual in any criminal case, excluding instances of perjury, giving a false statement, or obstruction of justice. ${ }^{187}$

The SEC's willingness to cooperate with a culpable whistleblower has proven to be successful, as the SEC reported an increase in the quality of tips it has received since the enactment of Dodd-Frank and adoption of the Cooperation Policy. ${ }^{188}$ From the establishment of the policy in August 2011 until the end of fiscal year 2013, the SEC reports that it has received 10,193 tips from whistleblowers. ${ }^{189}$

Similarly, the IRS already has a system in place in which it offers leniency to those who voluntarily provide it with information. The

183. Robert S. Khuzami, Dir. of Div. of Enforcement, Speech by SEC Staff: Remarks at News Conference Announcing Enforcement Cooperation Initiative and New Senior Leaders, SEC. \& EXCH. COMM’N (Jan. 13, 2010), http://www.sec.gov/news/speech/2010/ spch011310rsk.htm.

184. Id.

185. Office of Chief Counsel, Sec. \& Exch. Comm'N, Enforcement Manual 132-34

(2013), http://www.sec.gov/divisions/enforce/enforcementmanual.pdf.

186. Id. at 132 .

187. Id.

188. Christina N. Davilas \& Steven W. Hansen, SEC Announces First Deferred Prosecution Agreement With An Individual, BinghAM, Nov. 22, 2013, https://www.bingham.com/Alerts/2013/11/SEC-Announces-First-Deferred-ProsecutionAgreement-With-An-Individual.

189. Id.; see SEC. \& EXCH. COMM'N, 2014 AnNuAl Report on the DodD-Frank WHISTLEBLOWER PROGRAM 20 (2014), available at http://www.sec.gov/about/offices/ owb/annual-report-2014.pdf (discussing whistleblower tips and incentives in fiscal year 2013). 
existence of this program and the fact that Bradley Birkenfeld had the possibility of being granted immunity offer support for the suggestion that cooperation measures already in existence may be sufficient to incentivize culpable whistleblowers to report to the IRS, ${ }^{190}$ which would eliminate the need to make any bounties available to whistleblowers who are criminally convicted.

The Criminal Investigation ("CI") unit of the IRS possesses the power to decide whether criminal prosecution for tax violations is merited. ${ }^{191} \mathrm{CI}$ is the criminal enforcement arm of the IRS that investigates potential criminal tax violations and related financial crimes. It consists of special agents who are trained in unique investigatory skills, computer evidence, and forensic technology to recover financial data that may be hidden by electronic means such as encryption or password protection. ${ }^{192}$ Once CI detects fraud, it conducts a criminal investigation to obtain evidence, including "interviews of third party witnesses, conducting surveillance, executing search warrants, subpoenaing bank records, and reviewing financial data." 193 After all of the evidence is collected and analyzed, CI special agents will either determine that no criminal activity has been substantiated and discontinue the investigation or, if sufficient evidence of criminal activity has been found, prepare a written report of the findings and recommend prosecution. ${ }^{194}$ These special agent reports are then reviewed by several other layers within CI and are then forwarded to the Tax Division of the Department of Justice for prosecution, which, if accepted, will allow the CI special agent to assist prosecutors in preparing for trial. ${ }^{195}$ The IRS is clear that "[t]he ultimate goal of an IRS Criminal Investigation prosecution recommendation is to obtain a conviction or plea," suggesting approximately 3,000 criminal prosecutions per year. ${ }^{196}$

In determining whether a criminal prosecution should be recommended, CI must find that the evidence is sufficient to "establish guilt beyond a reasonable doubt and a reasonable probability of conviction

190. See Samantha H. Scavron, In Pursuit of Offshore Tax Evaders: The Increased Importance of International Cooperation in Tax Treaty Negotiations after United States $v$. UBS AG, 9 CARDOZO PUB. L. POL'Y \& ETHICS J. 157, 181 (2010) (noting that there may now be less of an incentive for complicit whistleblowers to come forward given Birkenfeld's prosecution and incarceration).

191. Criminal Investigation (CI) At-A-Glance, INTERNAL RevenuE SERV., http://www.irs.gov/uac/Criminal-Investigation-(CI)-At-a-Glance (last visited Feb. 25, 2015).

192. Id.

193. How Criminal Investigations are Initiated, INTERNAL REvENUE SERV., http://www.irs.gov/uac/How-Criminal-Investigations-Are-Initiated (last visited Feb. 25, 2015).

194. Id.

195. Id.

196. Id. 
must exist.” ${ }^{197}$ In making this determination, CI will consider factors such as "whether a voluntary disclosure was made, whether dual or successive prosecution exists, the health, age and mental condition of the taxpayer and whether solicitation of returns has occurred. The presence of any of the foregoing may impact on willfulness and significantly impair or eliminate the probability of conviction." " 198 Therefore, it is fully within the IRS's discretion to determine whether criminal prosecution is appropriate.

Although a voluntary disclosure on the part of the noncompliant taxpayer will not guarantee immunity outright, leniency for individuals who have voluntarily come forward with information is a long-standing IRS practice. ${ }^{199}$ As the Internal Revenue Service Manual clearly states, a "voluntary disclosure may result in prosecution not being recommended." 200 A voluntary disclosure occurs when a communication is made to the IRS that is:

truthful, timely, and complete, and when: (A) [t]he taxpayer shows a willingness to cooperate (and does in fact cooperate) with the IRS in determining his or her correct tax liability; and (B) [t]he taxpayer makes good faith arrangements with the IRS to pay in full the tax, interest, and any penalties determined by the IRS to be applicable. ${ }^{201}$

Disclosures will only be considered voluntary if a CI investigation has not yet been made. ${ }^{202}$

The IRS will provide leniency to those who voluntarily disclose information because incentivizing individuals or businesses that are liable

197. InTERnAL ReVEnUE SERVICE MANUAL $\S$ 38.3.1.3 (2004), available at http://www.irs.gov/irm/part38/irm_38-003-001.html [hereinafter IRS MANUAL].

198. Id.

199. Id. § 38.3.1.3.1; see Offshore Voluntary Disclosure Program Frequently Asked Questions and Answers, INTERNAL REVENUE SERV., http://www.irs.gov/Individuals/ International-Taxpayers/Offshore-Voluntary-Disclosure-Program-Frequently-AskedQuestions-and-Answers-2012-Revised (last visited Feb. 25, 2015) (stating that the CI takes voluntary disclosures into account when recommending whether an offender should be criminally prosecuted); 2012 Offshore Voluntary Disclosure Program, INTERNAL REVENUE SERV., http://www.irs.gov/uac/2012-Offshore-Voluntary-Disclosure-Program (last visited Feb. 25, 2015) (noting that the IRS has instituted a program to work with taxpayers who voluntarily come forward in order to reduce their penalties); The Use of Voluntary Disclosure Initiatives, supra note 82, at 499 (noting the IRS's long history of encouraging voluntary disclosure of tax evasion).

200. IRS MANUAL, supra note 197, § 38.3.1.3.1.

201. Id.

202. Id.; Marcotte, supra note 88, at 7 (noting that the IRS will generally not recommend any criminal prosecution "[a]s long as a taxpayer makes a truthful, timely, and complete disclosure before the disclosed information is discovered by the government”). 
to come forward with information is of utmost importance in the tax arena. ${ }^{203}$ "The compliance function of IRS is principally concerned with protecting and enhancing voluntarily compliant conduct by taxpayers." 204 The IRS relies extensively on the honesty of taxpayers in reporting their income in a system where "[m]any taxpayers are not willing to assist the IRS” by providing accurate and truthful tax returns. ${ }^{205}$ Dishonesty of taxpayers has given rise to the ever-growing "tax gap," 206 which is the difference between the amount of taxes that are owed to the government and those that are actually collected. ${ }^{207}$ The IRS's last report of the tax gap was made in 2006, which revealed that the gap for that year was $\$ 450$ billion, up from the $\$ 345$ billion that was previously reported in $2001 .^{208}$ Research has revealed that the tax gap has steadily increased since $1973 .{ }^{209}$

IRS leniency initiatives for voluntary disclosure have proven successful. After the IRS discovered the details of the UBS tax fraud through Bradley Birkenfeld, ${ }^{210}$ it created the first official voluntary disclosure program for delinquent taxpayers in 2009, offering such persons the option to report past due taxes in return for reduced penalties, a reduced likelihood of criminal prosecution, or both. ${ }^{211}$ Due to the successes of the 2009 initiative, the IRS offered the program again in 2011 and 2012, proving enormously successful in allowing the IRS to resolve a large number of cases without tapping into the resources of lengthy investigations. $^{212}$ In June 2012, the IRS announced that its voluntary

203. David T. Moldenhauer, Penalty Protection Opinions and Advisor Conflicts of Interest, 27 AKRON TAX J. 55, 56 n.4 (2012).

204. Id. (quoting Am. Inst. Certified Pub. Accountants, Report on Civil Tax PENAlties: THE NEED FOR REFORM 2-3 (2009)).

205. Leah A. Kahl, Incriminatory Effects of Compliance with IRS Subpoenas for Personal Documents: An Analysis of Current Approaches, 5 WM. \& MARY BILL RTS. J. 323, 327 (1996) (discussing an IRS survey revealing that one-fifth of taxpayers cheat on their tax returns).

206. Morse, supra note 30, at 2.

207. Michelle M. Kwon, The Tax Man's Ethics: Four of the Hardest Ethical Questions for an IRS Lawyer, 9 CARdOzo Pub. L. Pol'y \& Ethics J. 371, 393 (2011).

208. The Tax Gap, InTERnAl Revenue SERV., http://www.irs.gov/uac/The-Tax-Gap (last visited Feb. 25, 2015).

209. Karie Davis-Nozemack, Unequal Burdens in EITC Compliance, 31 LAW \& INEQ. 37, 41 n.24 (2012) (citing James M. Bickley, Cong. Res. Serv., R42739, Tax Gap, Tax Enforcement, and Tax Complance Proposals in the 112th Congress 3-5 (2012)); Bret Wells, New Schedule UTP: “Uncertain Tax Positions in the Age of Transparency," 63 BAylor L. Rev. 392, 394-95 (2011); see James Alm \& Jay A. Soled, The Internal Revenue Code and Automobiles: A Case Study of Taxpayer Noncompliance, 14 FLA. TAX REV. 419, 419 (2013) (noting that the tax gap has remained large over the last decade).

210. See supra Section II.A (discussing Bradley Birkenfeld's voluntary disclosure).

211. The Use of Voluntary Disclosure Initiatives, supra note 82, at 501.

212. Offshore Voluntary Disclosure Program Frequently Asked Questions and Answers, INTERNAL REVENUE SERV., http://www.irs.gov/Individuals/International-Taxpayers/ 
disclosure programs had brought in more than $\$ 5$ billion in back taxes, interest, and penalties from over 33,000 voluntary disclosures made. ${ }^{213}$

Given the essential and historical role that voluntary disclosures have played in the recovery of billions of dollars of lost tax revenue, it is clear that the IRS is heavily reliant on the willingness of individuals, businesses, and whistleblowers in general to come forward. Due to the promise of reduced penalties and possible avoidance of criminal prosecution, sources have noted that voluntary disclosure programs help culpable individuals overcome the fear of being discovered and prosecuted. ${ }^{214}$ Given the notable successes of the program in detecting tax fraud and allowing thousands to avoid criminal prosecution, the program seems to offer a winwin situation for both a culpable whistleblower and the IRS.

\section{B. The "Planned and Initiated" Determination}

The amended IRS whistleblower program was modeled after the False Claims Act ("FCA"), ${ }^{215}$ which, as discussed in Section II.B, was enacted during the time of the Civil War and is premised on the notion that it "takes a rogue to catch a rogue." ${ }^{216}$ As discussed, the IRS will reduce a bounty award to a whistleblower who "planned and initiated" the action that led to the tax non-compliance and will deny a reward to a whistleblower who is convicted because of this role, while allowing bounties for all other convicted whistleblowers. ${ }^{217}$ The IRS whistleblower program's use of the words "planned and initiated" is taken directly from the FCA. Section 3730(d) of the FCA states that if a qui tam plaintiff planned and initiated

Offshore-Voluntary-Disclosure-Program-Frequently-Asked-Questions-and-Answers-2012Revised (last visited Feb. 25, 2015).

213. IRS Says Offshore Effort Tops \$5 Billion, Announces New Details on the Voluntary Disclosure Program and Closing of Offshore Loophole, INTERNAL REvEnUE SERV., http://www.irs.gov/uac/IRS-Says-Offshore-Effort-Tops-\$5-Billion,-Announces-New-

Details-on-the-Voluntary-Disclosure-Program-and-Closing-of-Offshore-Loophole (last visited Feb. 25, 2015).

214. See, e.g., Robert W. Wood, Should You Opt Out of IRS Offshore Amnesty?, ForBES (Oct. 4, 2013, 1:47 AM), http://www.forbes.com/sites/robertwood/2013/10/04/should-youopt-out-of-irs-offshore-amnesty (discussing the various considerations in opting out of the offshore voluntary disclosure program ); Miriam L. Fisher et al., IRS Provides Guidance for Ongoing Offshore Voluntary Disclosure Program, LAтнам \& WAтKins (July 19, 2012), www.lw.com/ongoing-offshore-voluntary-compliance. For an analysis of other ways in which the IRS whistleblower program may be improved, such as the imposition of an internal reporting requirement and anti-retaliation protections, see Aldinger, supra note 122, at $939-44$

215. Radack Letter, supra note 35, at 1; Kwon, supra note 104, at 457; Feldman \& Lobel, supra note 1 , at 1168.

216. See supra Section II.B (discussing the enactment of the FCA).

217. 26 U.S.C. § 7623(b)(3) (2012 \& Supp. I 2013). 
the wrongdoing upon which the action is based, his or her award may be reduced. $^{218}$ Notably, the FCA also states that if the qui tam plaintiff is convicted of criminal conduct arising from his or her role in the wrongdoing, he or she is barred from receiving any award and is dismissed from the action. ${ }^{219}$ Therefore, the IRS whistleblower program diverges from the FCA in that it makes bounties available to those who are convicted, an approach that none of the other federal whistleblower programs take.

Differentiating those who "planned and initiated" from those who participated in the violation to a lesser degree is obviously a key distinction to be made. It would have made the difference in whether Bradley Birkenfeld walked away with a \$104 million bounty. Despite the fact that the "planned and initiated" distinction is the only limitation on whether the IRS will grant a bounty to a criminally convicted whistleblower, Congress has provided no guidance as to the meaning of these words. ${ }^{220}$ On August 12, 2014, the IRS and Treasury Department issued final regulations implementing the amended IRS whistleblower program of Section 7623 after publishing proposed regulations on December 28, 2012. ${ }^{221}$ Under the final regulations, the IRS determines that a claimant planned and initiated the underlying acts if he or she:

(A) [d]esigned, structured, drafted, arranged, formed the plan leading to, or otherwise planned, an underlying act, (B) [t]ook steps to start, introduce, originate, set into motion, promote or otherwise initiate an underlying act, and (C) [k]new or had reason to know that an underpayment of tax or actions described in section 7623(a)(2) could result from planning and initiating the

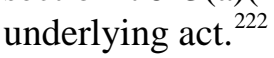

218. 31 U.S.C. § 3730(d)(3) (2012 \& Supp. I 2013) (emphasis added).

219. Id; see Kwon, supra note 104, at 458-60 (noting that while there are similarities between the FCA and the IRS whistleblower program, there are also differences, such as the whistleblower's more pronounced involvement in a qui tam action, court involvement in FCA actions as opposed to whistleblower claims with the IRS that are primarily administrative proceedings, and the requirement to prove that a defendant has defrauded the government in a qui tam action whereas fraud is not a prerequisite to receiving an award under the IRS whistleblower program- “ [ $t$ t]ax whistleblowers may recover from taxpayers' innocent mistakes or uncertainty in the tax laws.").

220. Awards for Information Relating to Detecting Underpayments of Tax or Violations of the Internal Revenue Laws, 77 Fed. Reg. 74,798, 74,803 (proposed Dec. 18, 2012) (to be codified at 26 C.F.R. pt. 301) [hereinafter Proposed IRS Rules].

221. Awards for Information Relating to Detecting Underpayments of Tax or Violations of the Internal Revenue Laws, 79 Fed. Reg. 47,246 (finalized Aug. 12, 2014) (to be codified at 26 C.F.R. pt. 301) [hereinafter Final IRS Rules].

222. Id. at 47,273. In the final regulations, the IRS and Treasury Department noted that 
If the IRS whistleblower office determines that a claimant meets the threshold for planning and initiating the underlying act, it will then categorize the extent to which that claimant was involved as "primary, significant, [or] moderate" and reduce the bounty accordingly. ${ }^{223}$ The regulations indicate that the "primary, significant or moderate" categories are intended to "promote consistency, fairness, and transparency in an award determination process that is inherently subjective."224 Once this determination is made, the IRS will reduce the awards by 67 to 100 percent for a primary planner or initiator, by 34 to 66 percent for a significant planner or initiator, and by 0 to 33 percent for a moderate planner or initiator. ${ }^{225}$

After the publication of the proposed regulations in December 2012, many commentators expressed concern that the IRS regulations expand the definition of "planned and initiated" beyond the original meaning of the words as evidenced by the FCA's legislative history, which considers whether the individual was the "principal architect" of the wrongdoing. ${ }^{226}$ Unfortunately, the legislative history of the 2006 amendments to the IRS whistleblower program does not shed light on these discrepancies, as any explanation of the rationale behind providing bounties to convicted whistleblowers and the intended meaning of "planned and initiated" is lacking. ${ }^{227}$ Commentators argued that the "planned and initiated" limitation should only "apply narrowly to principal wrongdoers" by encompassing those persons who "both originated, introduced or started the scheme and also designed, drafted and arranged the scheme."228

the whistleblower need not be the sole person involved in planning and initiating the act, rather "[a] whistleblower who merely furnishes typing, reproducing, or other mechanical assistance in implementing one or more underlying acts will not be treated as initiating any underlying act. A whistleblower who is a junior employee acting at the direction, and under the control, of a senior employee will not be treated as initiating any underlying act." Id.

223. Id.

224. Id. at 47,262 .

225. Id. at 47,273 .

226. Id at 47,261; Radack Letter, supra note 35, at 2; Public Hearing on Proposed Regulations 26 C.F.R. 1, Internal Revenue Serv., Awards for Information Relating to Detecting Underpayments of Tax or Violations of the Internal Revenue Laws (Apr. 10, 2013), [hereinafter IRS Public Hearings], http://www.taxwhistleblowerreport.com/ Unofficial\%20Transcript\%20Reg\%20Hearing\%20April\%202013.pdf (statement of Neil V. Getnick, Chairperson, Taxpayers Against Fraud Education Fund).

227. See Davis-Nozemack \& Webber, supra note 16, at 94 n.85 ("Little legislative history is available for the 2006 amendments. This is likely because the whistleblower amendments were only a small, uncontroversial part of the much larger Tax Relief and Health Care Act of 2006, enacted on December 20, 2006.”).

228. See Radack Letter, supra note 35, at 2-3 (citing 134 Cong. REC. S16697 (daily ed. Oct. 18, 1988) (statement of Senator Grassley) (stating that the amendment would "apply 
The proposed regulations included those who "knew or had reason to know that there were tax implications" as planners and initiators. ${ }^{229}$ Pinpointing the IRS's inclusion of contributors and advisors in this category, commentators argued that this category was unreasonably broad, straying from the original vision of Congress under the False Claims Act. ${ }^{230}$ Senator Grassley himself, the co-author of the 2006 amendments to the IRS whistleblower program, echoed these concerns, recognizing that "a delicate balance [needs] to be struck between weeding out bad actors while not discouraging knowledgeable insiders from coming forward."231

Others expressed concern that the examination of Bradley Birkenfeld's role in the UBS tax fraud offered no explanation of how the IRS will make the "planned and initiated" determination in the future. One source noted the probability that the IRS's determination with respect to Birkenfeld is not likely to help clarify how the IRS would distinguish between a whistleblower who "planned and initiated" the scheme and one who did not. ${ }^{232}$

The final regulations demonstrate the efforts of the IRS and Treasury Department to appease these concerns. Regardless, the "principal architect" approach was ultimately not adopted — the IRS notes that a single planner or initiator is not required in the statutory language, which provides for the possibility that multiple individuals may have planned or initiated a

narrowly to principal wrongdoers”); 124 CoNG. REC. H10637 (daily ed. Oct. 20, 1988) (statement of Rep. Berman) ("The amendment we are voting on today will allay any criticism that the False Claim [sic] Act will encourage principal wrongdoers to file false claims actions solely motivated by the desire to profit from their own previous wrongdoing”); 134 CoNG. REC. S16697 (daily ed. Oct. 18, 1988) (statement of Senator DeConcini) (expressing that the amendment was designed to prevent those who are "the main force behind a false claims scheme" from recovering)); see also IRS Public Hearings, supra note 226, at 23 (statement of Mr. Getnick) (expressing that the IRS's inclusion of "drafted" within the definition of "planned" "would seemingly penalize innocent employees who merely drafted a document at the direction of his or her superiors," and that the inclusion of "promoted" within the definition of "initiated" would "appear to penalize those who did not actually initiate anything but may only have become involved in the fraud scheme well after it began.”).

229. Proposed IRS Rules, supra note 221, at 74,803.

230. Radack Letter, supra note 35, at 3.

231. See Letter from Charles E. Grassley, U.S. Senator, to Dep’t. of Treasury and Internal Revenue Serv. (Jan. 28, 2013), at 3, available at http://kmblegal.com/wordpress/ wp-content/uploads/130128-Grassley-to-IRS-re-WB-Regs.pdf ("There is no reason for the IRS to be recreating the wheel with regard to planners and initiators. There is already established law in this area with respect to FCA claims.”).

232. Coder, supra note 95 (citing Barbara T. Kaplan of Greenberg Traurig LLP); see Saul Ewing LLP, supra note 78 ("[P]otential claimants and representatives are still left without full clarification as to exactly how much participation in a tax fraud scheme is permissible before the 'planned and initiated' exclusion applies.”). 
tax violation. ${ }^{233}$ The final regulations do change "knew or had reason to know that there were tax implications" to "knew or had reason to know that a tax underpayment or a violation of the internal revenue laws could result, ${ }^{234}$ which is more consistent with the specific tax matters that could be implicated.

In an effort to provide guidance as to how the planner/initiator role will be determined, the final regulations include five examples offering hypothetical factual scenarios to illustrate this determination. The regulations note that someone who merely furnishes assistance to another will not be treated as a planner/initiator, thereby ensuring that whistleblowers who are junior associates acting at the direction of a supervisor to conduct research or even draft documents would not be subject to a reduced bounty. ${ }^{235}$ Examples of whistleblowers meeting the planner/initiator determination, whether on a primary, significant or moderate level, involve a supervisor who incorrectly but in good faith designed a financial strategy resulting in tax deficiencies (moderate); an independent planner of a high-risk tax avoidance transaction that was subsequently approved by the company's officers and board of directors (significant); and a financial planner who designed a product that the IRS identified as an abusive tax avoidance scheme, marketed it, and disguised its true nature, resulting in tax penalties (primary). ${ }^{236}$

Although these examples shed light on the planner/initiator determination, they do not encompass the myriad scenarios and situations where one's level of involvement is uncertain or varied. In contrast, the SEC avoids this dilemma altogether by basing bounty eligibility not on the question of whether a whistleblower "planned and initiated" the wrongdoing but on whether the whistleblower was convicted for taking part, even narrowly, in the scheme. In this way, the eligibility determination turns on whether a prosecutor has decided to charge the whistleblower with a crime and whether that ultimately leads to a guilty plea or a verdict through the criminal justice system, rather than through an

233. Final IRS Rules, supra note 221, at 47,261.

234. Id.

235. Id. at 47,273-74. One hypothetical offers a situation in which a whistleblower is a human resources employee who organizes, schedules, and conducts job fairs to hire temporary, seasonal employees. Id. at 47,274. This whistleblower was not responsible for and had no knowledge of how the seasonal employees would be classified for federal tax purposes. Id. After discovering that the company had classified the seasonal employees hired as independent contractors, the whistleblower made a report to the IRS, which resulted in an investigation revealing deficiencies in tax payments and penalties. Id. Under these circumstances, the whistleblower's bounty would not be subject to a reduction because he/she did not know and had no reason to know that his/her actions could result in an underpayment of tax. Id.

236. Id. at 47,274 . 
assessment by an administrative agency that is subject to broad interpretations. Utilizing a criminal conviction as the measure of culpability for bounty eligibility avoids the potential confusion that emerges in attempting to determine whether an individual played a key role in a fraud as opposed to a more nominal role- - a distinction that is often hard to ascertain.

\section{RECENT SEC TRENDS}

This section is intended to anticipate counterarguments suggesting that the fields of tax law and securities law are so distinct as to justify their differences concerning culpable whistleblowers. In particular, it may be argued that securities fraud reporting is not comparable to tax fraud reporting and that their bounty incentive structures must, therefore, be different. ${ }^{237}$ The author does not dispute the fact that the IRS and the SEC are based on divergent fundamental missions. While the main tenet of the SEC is the disclosure of information to protect against the potential asymmetry of information between issuers of securities and investors in those securities, ${ }^{238}$ the mission of the IRS is to ensure that the public is compliant with their tax reporting obligations. ${ }^{239}$ While the two agencies

237. Dave Ebersole, Blowing the Whistle on the Dodd-Frank Whistleblower Provisions, 6 ENTREPRENEURIAL Bus. L.J. 123, 131 (2011) (citing Feldman \& Lobel, supra note 1, at 1193-95); cf. Ventry, supra note 172, at 448 (refuting the argument that tax law is so distinct from other areas of the law as to render comparisons to tax law too complex and ambiguous).

238. See The Investor's Advocate: How the SEC Protects Investors, Maintains Market Integrity, and Facilitates Capital Formation, SEC. \& ExCH. COMM'N, http://www.sec.gov/about/whatwedo.shtml (last visited Feb. 25, 2015) (“This [disclosure of information] provides a common pool of knowledge for all investors to use to judge for themselves whether to buy, sell, or hold a particular security. Only through the steady flow of timely, comprehensive, and accurate information can people make sound investment decisions.”); Paula J. Dalley, The Use and Misuse of Disclosure as a Regulatory System, 34 FLA. ST. U. L. REv. 1089, 1093-94, 1096 (2007) (noting that the securities acts established "[t]he archetype of the use of disclosure as a regulatory scheme ... [b]ecause information asymmetries cause market participants to demand compensatory premia, [and] a disclosure policy that reduces those asymmetries will improve the price-setting function of the market”). Commentators on the origins of federal securities regulation often quote Louis Brandeis, former associate justice of the U.S. Supreme Court, who famously expressed, "[s]unlight is ... the best of disinfectants ...." Dalley, supra, at 1096 (noting common reference to Louis D. Brandeis, Other People’s Money and How the Bankers Use It 92).

239. The Agency, Its Mission, and Statutory Authority, InTERnal Revenue SERV., http://www.irs.gov/uac/The-Agency,-its-Mission-and-Statutory-Authority (last visited Feb. 25, 2015); see David Freeman Engstrom, Whither Whistleblowing? Bounty Regimes, Regulatory Context, and the Challenge of Optimal Design, 15 THEORETICAL INQUIRIES IN L. 605, 625 (2014) (noting that "tax law is relatively determinate" in the sense that the Internal 
may have different goals, their need for information from complicit individuals is comparable. Such individuals, whether subject to investigation or penalties from either the IRS or SEC, may be incentivized to report through the desire for leniency or immunity.

Aside from drawing parallels due to a similar need for information, the identities of the two agencies have been converging. Recent trends have shown that the SEC and IRS, although designed to fulfill separate needs in the law, increasingly resemble each other in embodying the role of a "punisher." ${ }^{240}$ Legal scholars have begun to comment on the SEC's trend of utilizing tools that have traditionally been confined to the criminal enforcement arena. ${ }^{241}$

The statutory enforcement authority of the SEC does not include criminal sanctions, which are instead vested in the Department of Justice. ${ }^{242}$ In contrast, the IRS is a federal criminal investigative agency with the authority to utilize criminal police powers and sanctions, ${ }^{243}$ including search warrants, interrogations and surveillance. ${ }^{244}$ The SEC Enforcement Division, the entity tasked with the investigation of possible securities violations that recommends SEC action when appropriate, ${ }^{245}$ has increasingly redefined itself as a punishing entity, especially in the aftermath of the Bernie Madoff fraud and the SEC's inability to detect it sooner. ${ }^{246}$ As one scholar notes, the SEC "has recast itself as an all-purpose investigator and punisher" in recent times, removing roadblocks to initiating and pursuing investigations. ${ }^{247}$ At the time that the SEC began this shift, former SEC Chief of Enforcement Robert Khuzami recruited two former prosecutors from the U.S. Attorney's office rather than filling these

Revenue Code includes many "rule-like commands" as compared to other regulatory areas).

240. Miriam H. Baer, Choosing Punishment, 92 B.U. L. Rev. 577, 580, 610 (2012).

241. Id. at 610 (noting that the recent changes within the SEC's Enforcement Division, partially resulting from the discovery of Bernard Madoff's fraud in December 2008); Matthew P. Allen, The SEC Cooperation Initiative and Its Criminal Roots, MiLleR CANFIELD, Feb. 2013, at 1, available at http://www.millercanfield.com/publications-articles328.html; Steve Thorpe, Asked \& Answered: Matthew P. Allen on SEC Cooperation Initiative, Motion MAGAzINE, Apr. 23, 2011, available at http://www.legalnews.com/ oakland/1375212/; Russell G. Ryan, Don't Let the SEC Punish Too Harshly, BlOOMBERG, Aug. 15, 2012, http://www.bloomberg.com/news/2012-08-15/don-t-let-the-sec-punish-tooharshly.html (noting that "civil SEC remedies have no legitimate role in punishing crimes").

242. Allyson Poulos, Rachel Cox, Claire Burks \& Chandra Kurien, Securities Fraud, 50 AM. CRIM. L. REV. 1479, 1544 (2013).

243. Criminal Enforcement, Internal Revenue Serv., Feb. 4, 2014, http://www.irs.gov/uac/Criminal-Enforcement-1.

244. IRS MANUAL, supra note 197, §§ 9.4.5, 9.4.6, 9.4.9.

245. Division of Enforcement, SEC. \& ExCH. Comm’n (Jan. 30, 2013), http://www.sec. gov/divisions/enforce.shtml.

246. Baer, supra note 240, at 610 .

247. Id. 
positions with career SEC attorneys. ${ }^{248}$ Khuzami enacted a number of changes that were aimed at making the SEC Enforcement Division look and act more like a criminal law enforcement agency, ${ }^{249}$ including reorganizing the division into subject matter units dedicated to investigating specific types of noncompliance and an announcement of the intention to expand cooperation programs from entities to individual cooperators-a tool already used by criminal law enforcement. ${ }^{250}$

The 2013 appointment of Mary Jo White as Chair of the SEC, former U.S. Attorney for the Southern District of New York, is also a signal that the SEC is committed to increasing its role as a punishing entity using tools resembling criminal enforcement agencies. With a reputation as "a tough litigator," White, the first career prosecutor and litigator to chair the SEC, filled key positions in the enforcement division nearly instantaneously with people she knew well in that arena. ${ }^{251}$ Extensive public comment has noted the more aggressive tone that the SEC embodies due to White's role, including admissions of guilt by violators, the rejection of settlements to bring more cases to trial, and a growing perception that the SEC is "tougher" than it was before. ${ }^{252}$

The SEC Cooperation Policy discussed in Section III.A is one of the primary tools that the SEC has developed to improve its enforcement mechanisms, a program that was "mold[ed] ... in the image of criminal cooperation tools employed by the U.S. Department of Justice," thereby continuing the "criminalization" of the SEC's procedures and policies. ${ }^{253}$

248. Id.

249. Id. at 623

250. Id. at 610 .

251. Nicholas Lemann, Street Cop, The New Yorker, Nov. 11, 2013, available at http://www.newyorker.com/reporting/2013/11/11/131111fa_fact_lemann?currentPage=all.

252. See, e.g., Sheelah Kolhatkar, Mary Jo White Is the Woman Who Makes Wall Street

Admit Guilt, BlOOMBERG Bus. WEEK, Oct. 16, 2013, available at http://www.businessweek.com/articles/2013-10-16/mary-jo-white-is-the-woman-whomakes-wall-street-admit-guilt\#p2 (noting White's new policy of demanding admissions); Steven Perlberg, Why Friends Call SEC Chair Mary Jo White 'Sid Vicious,' Bus. InsIDER, Nov. 4, 2013, http://www.businessinsider.com/the-new-yorker-profile-of-mary-jo-white2013-1 (noting that White's appointment has created a "tougher" SEC); Emily Flitter \& Sarah Lynch, SEC Rejects Settlement with Fund Manager Phil Falcone, REUTERS, July 19, 2013, available at http://www.reuters.com/article/2013/07/19/us-sec-falcone-settlementidUSBRE96I0OF20130719 (discussing White's recent rejection of a proposed settlement with hedge fund manager Philip Falcone and White's intent "to be more aggressive in dealing with settlements and to take more cases to trial").

253. Allen, supra note 241, at 1; see Dina ElBoghdady, SEC Shows Leniency to HedgeFund Administrator in a First for Agency, WASH. Post, Nov. 12, 2013, http://www.washingtonpost.com/business/economy/sec-shows-leniency-to-hedge-fundadministrator-in-a-first-for-agency/2013/11/12/c976ae4e-4bce-11e3-be6b-

d3d28122e6d4_story.html (detailing the SEC's decision to “forego significant enforcement 
These tools include SEC requests for immunity from the U.S. Attorney General and deferred and non-prosecution agreements. ${ }^{254}$ The SEC's shift toward historically criminal tools demonstrates a greater emphasis "on the SEC's 'mission' to 'work cooperatively with criminal authorities, to share information, and to coordinate their investigations with parallel criminal investigations when appropriate.,”255

Criminal and civil law are clearly distinct. While criminal laws look to the existence of mens rea, or the defendant's guilty mind, civil laws tend to be concerned with liability from an objective standpoint. ${ }^{256}$ While civil suits provide redress for disputes between private persons or parties, criminal suits prosecuted by the government are intended to punish those whose conduct violates the moral judgments of society. ${ }^{257}$ The Supreme Court's recent examinations of the criminal/civil distinction have noted that the goals of deterrence, incapacitation, and rehabilitation do not alone have the capability of transforming a seeming civil statute into a criminal statute. $^{258}$ Instead, the Supreme Court has pinpointed that the key difference between criminal and civil law is that criminal law has a retributive purpose "authoriz[ing] the state to impose sanctions to express the community's blame or condemnation for the commission of an

action” against a former hedge fund administrator because he helped the SEC uncover fraud at his former fund); see also Gregory S. Bruch \& Elizabeth P. Gray, SEC Announces Measures to Encourage Cooperation and Names Specialized Unit Chiefs, THE METRO. Corporate Counsel, Mar. 2010, at 20, available at http://www.willkie.com/ /media/Files/ Publications/2010/03/SEC\%20Announces\%20Measures\%20to\%20Encourage\%20Cooperati on\%20_/Files/SEC\%20Announces\%20Measures\%20to\%20Encouragepdf/FileAttachment/ SEC\%20Announces\%20Measures\%20to\%20Encourage.pdf (describing how the SEC began to use deferred prosecution agreements and written cooperation agreements to incentivize whistleblowing); Gideon Mark, Private FCPA Enforcement, 49 AM. Bus. L.J. 419 (2012) (noting that the SEC first used a deferred prosecution agreement in 2011 and, together with the Department of Justice, the SEC entered into 29 deferred and non-prosecution agreements in 2011); Russell G. Ryan, Bill Would Put Dangerous Weapons in SEC Hands, Fin. ADVISOR (Aug. 16, 2012), http://www.fa-mag.com/news/-bill-would-put-dangerousweapons-in-sec-hands-11640.html (noting that Congress has been "incrementally blurring the line between civil regulatory enforcement and criminal punishment, reflecting an eerie indifference to due process and the proper constitutional allocation of law-enforcement responsibility").

254. Allen, supra note 241, at 1.

255. Id. at 2 (citing Office of Chief Counsel, Sec. \& EXCH. Comm’n, EnForcement MANUAL 104 (2013), available at http://www.sec.gov/divisions/enforce/ enforcementmanual.pdf.).

256. Id. at 4 (emphasis added).

257. John J. Cound, Jack H. Friedenthal, Arthur R. Miller \& John E. Sexton, Civil Procedure, Cases and Materials 2 (2001).

258. Symposium, Punishment Without Culpability, 102 J. CRIM. L. \& CRIMINOLOGY 653, 679-82 (2012) (citing Smith v. Doe, 538 U.S. 84 (2003); Kansas v. Hendricks, 521 U.S. 346, 350-54 (1997)). 
unlawful act.”259 Although objectives like deterrence and incapacitation are associated with punishment, these goals have also been found to be "compatible with" civil regulatory statutes, thereby failing to serve as the main factor that differentiates criminal law from civil law. ${ }^{260}$ The imposition of punishment thus distinguishes a criminally convicted individual from a culpable one. ${ }^{261}$ As legal scholar John F. Stinneford notes:

The centrality of retributive purpose in distinguishing criminal from civil laws reflects an obvious but often-overlooked fact: A defendant who is subjected to criminal punishment loses more than property or even liberty: he also loses his good name. He is labeled by the community as a person worthy of blame, stigma, and retribution. He is labeled a criminal. This is a very serious thing indeed, and it calls for the protections the Constitution affords criminal defendants. ${ }^{262}$

The fact that the SEC has increasingly manifested itself as having a retributive purpose utilizing criminal cooperation tools suggests that the line between these federal agencies may be becoming more blurred. Such a premise may serve to challenge the perception that the SEC and IRS are so distinct as to justify any varying treatment of criminally convicted whistleblowers.

\section{CONCLUSION}

As early as the Civil War era, the False Claims Act's theory that it "takes a rogue to catch a rogue" 263 has justified rewarding those with unclean hands for the valuable information that they are able to provide. The legacy of these words was applied to both the IRS whistleblower program, as amended in 2006, and the SEC whistleblower program under Dodd-Frank, each of which provide bounties to whistleblowers who are complicit in the wrongdoings for which they are reporting. Both federal agencies have decided not to exclude culpable whistleblowers from being eligible for a bounty, but they diverge with respect to making bounties available to whistleblowers who are criminally convicted. The SEC whistleblower program follows the False Claims Act model in that it will

259. Id. at 683

260. Id.

261. Id.

262. Id.

263. See supra Section II.B. 
outright deny a bounty to any convict, ${ }^{264}$ and, for a whistleblower who participated in the wrongdoing but was not convicted, will reduce the amount of the bounty based on such person's level of involvement. ${ }^{265}$ In contrast, the IRS will allow bounties even for criminally convicted whistleblowers as long as they were not convicted because they "planned and initiated" the wrongdoing. ${ }^{266}$

Bradley Birkenfeld's contributions as a whistleblower were invaluable in bringing one of the most significant tax frauds to light, leading to initiatives that helped the U.S. government tap into the recesses of Swiss bank secrecy. ${ }^{267}$ Despite Birkenfeld's legal battle for immunity, he was denied this opportunity for failure to disclose the extent of his criminal involvement. ${ }^{268}$ Birkenfeld's $\$ 104$ million bounty is controversial and threatens long-standing legal principles holding that convicts should be precluded from financially benefitting from their misdeeds. ${ }^{269}$

This Article has suggested that the incentives of leniency and immunity already inherent in SEC and IRS programs provide enough of an incentive to whistleblowers who are likely to be successfully prosecuted, with Bradley Birkenfeld's story being a case in point. By amending the IRS whistleblower program to follow that of the SEC model, Congress would more closely adhere to the legacy of the False Claims Act-the statute upon which the present-day IRS program is based and that denies bounties to whistleblowers who are criminally convicted. Such amendments would also eliminate the lack of clarity stemming from the IRS whistleblower program's current use of the "planning and initiating" limitation, which differentiates those who are denied a bounty outright because of a conviction for this role from those who are not. ${ }^{270}$ Commentators have already begun to critique the way in which the IRS makes this determination, citing its lack of guidance and divergence from comparable reporting systems. ${ }^{271}$

Finally, this Article has acknowledged the distinctions between the areas of tax and securities law but has challenged any possible counterarguments that may critique this Article's position based on these differences. Recent trends have revealed that the SEC has emerged as a "punisher" utilizing investigatory and enforcement tools that are more akin to its criminal counterparts, such as the IRS and the Department of

264. See supra Section I.B

265. Id.

266. See supra Section I.A.

267. See supra Section II.A.

268. Id.

269. See supra Section III.

270. See supra Section III.B.

271. Id. 
Justice. $^{272}$ Such trends suggest that perhaps the SEC and IRS are not so different after all, especially in light of the significant need of both agencies to be informed of fraud and other violations of the law.

Martin Luther King Jr. once eloquently expressed that "[h]e who passively accepts evil is as much involved in it as he who helps to perpetrate it. He who accepts evil without protesting against it is really cooperating with it.”273 These words tell us that even silence is complicity, which may suggest that an individual who observes wrongdoing in silence, taking no action, may have the same level of fault as a participator in the wrongdoing who then reveals it. For this reason, culpable whistleblowers should be acknowledged and rewarded for the inside information that only they can provide, but with caution. Barring the criminally convictedpersons who have undergone criminal prosecution resulting in an ascertainment of guilt-from whistleblower bounties is likely to be a reasonable solution to the conflict between incentivizing those with unclean hands to inform the government of fraud and avoiding the possibility that their motivations are merely premised on the promise of potentially millions of dollars.

272. See supra Section IV.

273. Martin Luther King, JR., Stride Toward Freedom: The Montgomery Story 51 (1958). 